\title{
Tomasz Pudeocki
}

(iD https://orcid.org/0000-0001-7527-0919

Uniwersytet Jagielloński

\section{Gimnazjum w Samborze za czasów dyrektury Franciszka Tomaszewskiego (1896-1904)}

\section{Wstęp}

Dzieje Gimnazjum w Samborze, mieście położonym na pograniczu polsko-ukraińskim, doczekały się całościowego ujęcia ${ }^{1}$. Nie oznacza to wcale, że tematyka nie pozostawia wielu pól badawczych ${ }^{2}$. Niniejszy artykuł jest kontynuacją i rozszerzeniem moich badań nad środowiskiem szkolnym samborskiego gimnazjum oraz nad postacią Franciszka Tomaszewskiego. Ten nauczyciel, dyrektor, poseł do organów ustawodawczych we Lwowie i w Wiedniu był bowiem jedną z najbardziej aktywnych postaci swego pokolenia - wcielał w życie postulaty pozytywistycznego przekształcania świata i ludzi w jednostki bardziej świadome i zaangażowane społecznie.

* Autor dziękuje mgr Ewie Nizińskiej za wszelkie uwagi i sugestie.

1 М. Кріль, Самбірська гімназія, шлях у 225 років, т. 1, Дрогобич 2017; recenzję zob. T. Pudłocki, Михайло Кріль: Самбірська гімназія, шлях у 225 років, том 1, Дрогобич, жуd. Коло 2017, ss. 806, „Kwartalnik Historii Nauki i Techniki” R. 63, 2018, nr 3, s. 137-143. Zob. tеż: М. Крі ль, Самбірська гімназія. Від заснування до „весни народів” (до 225-річчя від заснування), „Дрогобицький краєзнавчий збірник” 2017, вип. 3 (вип. спец.), s. 31-44.

${ }_{2}$ T. Pudłocki, Franciszek Tomaszewski i njegovo putovanje po hrvatskim krajevima, „Historijski zbornik" [Zagrzeb] 2016, vol. 68, No. 2, s. 385-410; idem, Gimnazjum im. Arcyksiężniczki Elżbiety $w$ Samborze w okresie dyrektury Józefa Szafrana (1904-1914), [w:] Galicja - mozaika nie tylko narodo$w a$, t. 4, red. U. Jakubowska, Warszawa 2017, s. 95-124. Zob. też ze starszej literatury: A. Kuczera, Samborszczyzna. Ilustrowana monografia miasta Sambora i ekonomii samborskiej, t. 2, Sambor 1937, s. 365-368. 
Sambor, leżący pomiędzy Przemyślem a Drohobyczem, na przełomie XIX i XX w. miał największą procentowo liczbę Polaków w całej Galicji Wschodniej, a w ostatnich dziesięcioleciach istnienia Monarchii Habsburskiej miasto jeszcze się polonizowało - posiadając przy tym ważną i aktywną mniejszość żydowską i ukraińską (w tej kolejności jeżeli chodzi o wielkość) ${ }^{3}$. Niemałą rolę w kształtowaniu miejscowych stosunków odgrywało gimnazjum - jedno ze starszych w Galicji i posiadające piękne tradycje kształcenia. Tak miasto przełomu XIX i XX w. wspominała Helena z Gotkowskich Kozicka:

Budowano wtedy linię kolejową Sambor-Sianki, a w mieście roiło się od młodych inżynierów, było więc gwarno i wesoło. Miasto małe, ładnie położne, czyste, pyszna kąpiel w Dniestrze, życie towarzyskie rozwinięte. Niezwykłością było współżycie z inteligencją żydowską [...]. Stosunki towarzyskie w Samborze były najmilsze właśnie dzięki rozmaitości typów ludzkich ${ }^{4}$.

$\mathrm{W}$ artykule chciałbym przyjrzeć się środowisku szkolnemu miejscowego gimnazjum ze szczególnym uwzględnieniem postaci jego kierownika - dyrektora dr. Franciszka Tomaszewskiego - a, także określić, na ile predyspozycje i umiejętności, zainteresowania naukowe i jego charakter wpływały na życie zarówno powierzonej mu placówki, jak i Sambora. Pomimo iż wybrane lata, obejmujące cały okres dyrektury Tomaszewskiego, stanowią zaledwie drobny wyimek z dziejów Grodu Spytkowego, to szczegółowa analiza przykładów działalności wpływowej jednostki pozwoli mi uchwycić fenomen znaczenia pojedynczych osób w kreowaniu środowiska. Znaczenie dyrektora jedynej wówczas szkoły średniej w dystrybuowaniu wzorców, norm, ale i władzy w zaledwie 20-tysięcznym mieście było bowiem znaczne. Tematyka warta jest bliższemu przypatrzeniu się i odpowiedzeniu na pytanie, w jaki sposób wpływ ten powstawał oraz jakie przynosił efekty. Naturalnie trudno jednej osobie przypisywać całokształt wszystkich działań podejmowanych w szkole (a tym bardziej w mieście), zwłaszcza że i poprzedni dyrektorzy aktywnie włączali się w realizowanie pozytywistycznego wzorca misji inteligenckiej, niemniej jednak nie zaszli tak wysoko w hierarchii miejscowych układów społecznych, jak Tomaszewski.

\section{Rys postaci}

Franciszek Tomaszewski urodził się 30 września 1852 r. w Brzeżanach, gdzie skończył gimnazjum. Przez rok uczęszczał na Wydział Filozoficzny Uniwersytetu Lwowskiego, po czym spędził cztery lata w Wiedniu ${ }^{5}$, studiując matematykę i fizykę. Pochodził ze stosunkowo ubogiej rodziny, przez co - jak pisano po latach - „literalnie o suchym chlebie spędzał początkowo pierwsze lata studiów uniwersyteckich

${ }^{3}$ I. Weinfeld, Ludność miejska Galicji i jej skład wyznaniowy (1881-1910), „Wiadomości Statyczne o Stosunkach Krajowych" 1912, t. 24, z. 2, s. 17, 22, 26.

${ }^{4}$ H. z Gostkowskich Kozicka, Wspomnienia z lat 1867-1914, oprac. K. Cybulska, Kielce 2015, s. 157,159 .

5 „Słowo Polskie” R. 17, 1912, nr 330 z 18 VII, s. 1. 
w Wiedniu"6. Dorabiał - jak duża liczba ubogich studentów - korepetycjami. Po zakończeniu studiów, w 1876 r., złożył egzamin nauczycielski z matematyki i fizyki, z wykładowymi językami polskim i niemieckim, przed Komisją Egzaminów Nauczycielskich w Wiedniu?

Następnie, w latach 1876-1879, pracował jako zastępca nauczyciela we lwowskim gimnazjum im. Franciszka Józefa. W dn. 19 września 1879 r. został mianowany nauczycielem przez Radę Szkolną Krajową w gimnazjum w Przemyślu. Po roku, 6 sierpnia 1880 r., przeniesiono go do gimnazjum św. Anny w Krakowie ${ }^{8}$. Anonimowy jego wychowanek z czasów krakowskich (1881-1883) w takich słowach wspominał swego nauczyciela fizyki i chemii:

Cechami najwybitniejszymi Franciszka Tomaszewskiego były: pracowitość niezmordowana i prawość charakteru. A z tej pracowitości i z tej szczerości charakteru wynikał trzeci przymiot, nader cenny - wielki optymizm życiowy: pogoda umysłu, wiara w ludzi, spora doza rozumnej i ładnej filozofii życiowej, która, nie będąc oportunizmem, uczy przecież brać rzeczy i ludzi takimi, jakimi są, i bronić się od niepotrzebnych rozczarowań. [...] Na nas, uczniów VII klasy [...] robił wrażenie bardzo inteligentnego nauczyciela, który umiał wykładać doskonale i wykład swój przeplatać aktualnymi uwagami z rozmaitych dziedzin życia ludzkiego'.

Jako nauczyciel gimnazjalny w Krakowie udzielał dodatkowo lekcji na kursach wydziałowych dla nauczycieli szkół ludowych, a także przez 16 lat był członkiem Komisji Egzaminacyjnej dla kandydatów na ochotników jednorocznych przy Korpusie Komendy w Krakowie ${ }^{10}$. Przez jedenaście lat był pomocniczym nauczycielem w państwowej szkole przemysłowej; ponadto przez piętnaście lat wykładał fizykę na kursach A. Baranieckiego ${ }^{11}$. Aktywnie działał także w miejscowym Kole Towarzystwa Nauczycieli Szkół Wyższych, a 16 stycznia 1887 r. został wybrany sekretarzem krakowskiego oddziału ${ }^{12}$. W dn. 16 grudnia 1887 r. uzyskał stopień naukowy doktora na Wydziale Filozoficznym Uniwersytetu Jagiellońskiego z zakresu fizyki i chemii ${ }^{13}$.

Franciszek Józef I decyzją z dn. 30 sierpnia 1896 r. mianował go dyrektorem gimnazjum im. arcyksiężniczki Elżbiety w Samborze ${ }^{14}$. Był to niewątpliwy awans zawodowy i dostrzeżenie jego dotychczasowego zaangażowania w pracy zawodowej

${ }^{6}$ Śp. Franciszek Tomaszewski, Wiedeń, 19 lipca, „Słowo Polskie” R. 17, 1912, nr 335 z 20 VII, s. 2.

7 „Muzeum” 1912, t. 28, s. 234.

${ }^{8}$ Sprawozdanie Dyrekcji c.k. Gimnazjum w Przemyślu za r. szk. 1880, Przemyśl 1880, s. 65; Sprawozdanie Dyrekcji c.k. Gimnazjum w Przemyślu za r. szk. 1881, Przemyśl 1881, s. 57; „Muzeum” 1912, t. 28 , s. 234.

${ }^{9}$ Śp. Franciszek Tomaszewski, Wiedeń, 19 lipca, „Słowo Polskie” R. 17, 1912, nr 335 z 20 VII, s. 2.

10 Sprawozdanie Dyrekcji c.k. Gimnazjum im. Arcyksiężniczki Elżbiety w Samborze za rok 1897, Sambor 1897, s. 4.

11 „Muzeum” 1912, t. 28, s. 235.

12 M. Warm ski, Towarzystwa Nauczycieli Szkół Wyższych 1884-1894. Rys historyczny, Lwów 1894, s. 40; „Muzeum” 1887, t. 3, s. 54-57.

13 „Muzeum” 1912, t. 28, s. 234.

${ }_{14}$ Sprawozdanie Dyrekcji c.k. Gimnazjum im. Arcyksiężniczki Elżbiety w Samborze za rok 1897, Sambor 1897, s. 4. 
i społecznej. Po kilku latach, decyzją cesarską z dn. 28 września 1904 r. mianowano go dyrektorem gimnazjum im. Franciszka Józefa we Lwowie ${ }^{15}$. Bardzo szybko i w tym mieście zasłynął $\mathrm{z}$ aktywności i energii, angażując się w działalność szeregu organizacji $^{16}$. Jako dyrektor założył w 1907 r. fundusz wsparcia i bursę dla ubogich uczniów $\mathrm{im}$. Stefana Batorego, przy ul. Jabłonowskich $11^{17}$. Ze względu na zaangażowanie politycznie, obowiązków dyrektorskich nie pełnił długo. Po wyborze na posła do Rady Państwa, od 1 września 1907 r. stale przebywał na urlopie ${ }^{18}$. Do pracy w gimnazjum już nigdy nie powrócił, bowiem po przegranych wyborach Rada Szkolna Krajowa 12 stycznia 1912 r. udzieliła mu na r. szk. 1911/1912 zniżki godzin dla podratowania zdrowia. Niewiele to dało - wkrótce bowiem zmarł.

Poza pracą oświatową i społeczną wiele czasu poświęcał polityce. W roku $1901 \mathrm{r}$. został posłem do Sejmu Krajowego, gdzie zasiadał przez sześć lat. W czerwcu 1907 r. wybrano go posłem do Rady Państwa z V okręgu miasta Lwowa - jako kandydat Narodowej Demokracji ${ }^{19}$. Stanisław Głąbiński tak mówił o nim podczas pogrzebu:

[...] odczuwał śp. Franciszek Tomaszewski, że Polak nie może zaznać prawdziwego szczęścia, dopóki nie będzie go w Ojczyźnie, i szukał sposobności do szerszej pracy narodowej. Szukał jej w pracy dla młodzieży, dla nauczycielstwa, dla miasta i kraju, w szkole i poza szkołą, a na każdym posterunku był wzorem Polaka obywatela. [...] wszędzie cechowało go [...] surowe poczucie obowiązków i wielkie wymogi do samego siebie. Pracy nigdy dość nie miał, ciągle szukał nowej. Nieraz w Wiedniu wyrażał życzenie, aby mu dać

${ }^{15}$ Sprawozdanie Dyrekcji c.k. Gimnazjum im. Arcyksiężniczki Elżbiety w Samborze za rok 1905, Sambor 1905, s. VI; Sprawozdanie Dyrekcji c.k. III Gimnazjum im. cesarza Franciszka Józefa we Lwowie za rok szkolny 1905, Lwów 1905, s. 1.

${ }^{16}$ W 1905 r. został wybrany radnym miejskim, a od 1906 r. członkiem miejskiej Rady Szkolnej Okręgowej. Wybrano go też prezesem Towarzystwa Oświaty Ludowej (funkcję tę pełnił do 1908 r.). Krótko był wiceprezesem Koła Literacko-Naukowego, Towarzystwa Kolonii Rymanowskiej, a także członkiem Rady Szkolnej Krajowej. W 1907 r. został przewodniczącym Polskiego Towarzystwa Pedagogicznego. Za jego czasów czołowy organ prasowy PTP „Szkoła” został przemianowany na miesięcznik, a jego poziom został znacznie podniesiony. Z inicjatywy Tomaszewskiego zwołano też w 1909 r. I Kongres Pedagogiczny we Lwowie - zob. Sprawozdanie Dyrekcji c.k. III Gimnazjum im. cesarza Franciszka Józefa we Lwowie za rok szkolny 1905, Lwów 1905, s. 1, 5; Sprawozdanie Dyrekcji c.k. III Gimnazjum im. cesarza Franciszka Józefa we Lwowie za rok szkolny 1907, Lwów 1907, s. 55; „Słowo Polskie” R. 17, 1912, $\mathrm{nr} 330$ z 18 VII, s. 1; J. Kornicki, op. cit., s. 2.

17 „Słowo Polskie” R. 17, 1912, nr 361 z 5 VIII, s. 8.

18 Sprawozdanie Dyrekcji c.k. III Gimnazjum im. cesarza Franciszka Józefa we Lwowie za rok szkolny 1908, Lwów 1908, s. 23; Sprawozdanie Dyrekcji c.k. III Gimnazjum im. cesarza Franciszka Józefa we Lwowie za rok szkolny 1910, Lwów 1910, s. 33; Sprawozdanie Dyrekcji c.k. III Gimnazjum im. cesarza Franciszka Józefa we Lwowie za rok szkolny 1911, Lwów 1911, s. 23.

${ }_{19}$ W Wiedniu zabierał głos głównie w sprawach szkolnych, m.in. przeciwstawiając się roszczeniom Ukraińców i dementując zarzuty posłów ukraińskich o nierespektowaniu praw oświatowych tej mniejszości. Złożył projekt stworzenia Rady Pedagogicznej przy Ministerstwie Wyznań i Oświaty, co jednak nie zostało ostatecznie zrealizowane. Był członkiem parlamentarnej Komisji ds. Urzędniczych, Komisji Podatkowej, Komisji Socjalno-Politycznej, Szkolnej i Przemysłowej. Komisja Urzędnicza powierzyła mu referat trzeciego działu pragmatyki służbowej o prawach urzędników i o oficjantach pocztowych. Jak pisał Jan Kornicki, odnosząc się do aktywności Tomaszewskiego w życiu publicznym: „Jego serdeczną troskę o losy nauczycielstwa podziwialiśmy niejednokrotnie, gdy za najdrobniejszymi nieraz sprawami osobistymi nauczycieli biegał czy to w Ministerstwie Oświaty, czy w Radzie Szkolnej [Krajowej] tak długo, aż zostały pomyślnie załatwione" - zob. J. Kornicki, op. cit., s. 2. 
w Kole Polskim i w parlamencie szersze pole do pracy, bo sumienie obywatelskie spocząć mu nie pozwala ${ }^{20}$.

Bardzo aktywny tryb życia odbił się mocno na jego zdrowiu. Już w 1910 r. zaczął poważnie chorować. To nie pozwoliło mu aktywnie włączyć się w walkę o reelekcję, którą przegrał ${ }^{21}$. W 1911 r. przeszedł ciężką operację. Pomimo tego nie zarzucił dotychczasowej aktywności, wydając broszurę o konieczności zasilania finansów szkolnych miasta Lwowa przez fundusz krajowy. Po przegranych wyborach z dużym zapałem powrócił do obowiązków dyrektorskich w III Gimnazjum, choć miał prawo do emerytury. Miał mówić:

Jestem za młody [...] aby nic nie robić. Mandatu nie dostałem, ale chcę pracować, wrócę tedy do pracy nauczycielskiej ${ }^{22}$.

Tomaszewski poza oświatą i polityką pozostawił po sobie znaczny dorobek naukowy, głównie z zakresu fizyki i chemii ${ }^{23}$. Drugą dziedziną naukową, w której się wypowiadał, była pedagogika. Ogłosił m.in.: W sprawie uroczystych obchodów szkol-

20 „Słowo Polskie” R. 17, 1912, nr 334 z 20 VII, s. 3.

21 Wiadomo, że 10 I 1911 r. składał relację ze swoich czynności przed wyborcami V okręgu zob. „Słowo Polskie” R. 16, 1911, nr 17 z 17 I, s. 2. Kampanię wyborczą w swoim okręgu rozpoczął 23 V 1911 r., o czym szczegółowo informowało swoich czytelników „Słowo Polskie” (ibidem, nr 240 z 24 V, s. 1). Zob. też: jego mowę z tego dnia wydrukowaną w Nadzwyczajnym dodatku do nru 241 „Słowa Polskiego" (z 24 V, s. 9-10).

${ }_{22}$ Śp. Franciszek Tomaszewski, Wiedeń, 19 lipca, „Słowo Polskie” R. 17, 1912, nr 335 z 20 VII, s. 2.

${ }^{23}$ Odczyty dra Ochorowicza o elektryczności zwierzęcej statycznej jako istocie magnetyzmu zwierzęcego (jako odbitka z „Przeglądu Lekarskiego” 1882); Szkice z dziejów elektrotechniki, „Biblioteka Warszawska” 1883; O świecie elektrycznym, „Czas” 1883; O niektórych nowych teoriach $w$ dziedzinie fizyki kosmicznej (jako odbitka z czasopisma „Kosmos” 1884); Wpływ ciał niebieskich na pogodę, „Nowa Reforma” 1886; Przyczynek do znajomości stałej dialektycznej płynów, „Pamiętnik Akademii Umiejętności. Wydział Matematyczno-Przyrodniczy” 1888, t. 14, s. 101-115 (przedruk po niemiecku jako Beitrag zum Kenntnis Dielectriectälsconsonante der Flüssigkeiten, w „Annalen der Physik und Chemie” (Leipzig) 1888, Bd. 23, s. 33-42; też jako osobna odbitka wydana w Lipsku w 1888 r. oraz po polsku w Krakowie w 1887 r.); O poprawnym fonogramie Edisona, „Nowa Reforma” 1890; Rozwój teorii fizycznych, „Przegląd Powszechny" 1891, t. 30, s. 101-113, 196-207 (też jako osobna odbitka, Kraków 1891); Ein Einfaches Demonstrationes-Elektrometer, „Zeitung für den physiche und chemische Unterricht” 1892; Ein einfache Kirchoff-Wheastonische Brücke, „Zeitung für den physische und chemische Unterricht” 1892 (za opisywany i sporządzony przyrząd otrzymał brązowy model na Wystawie Krajowej we Lwowie w 1894); O telefonie, „Nowa Reforma” 1893; Oświetlenie elektryczne nowego teatru krakowskiego, „Czasopismo Techniczne” 1894; Promienie Röntgena, „Czasopismo Techniczne” 1896; Promienie Röntgena, [w:] Sprawozdanie dyrekcji Gimnazjum św. Elżbiety w Samborze za rok szkolny 1901, Sambor 1902 (s. 3-79) - też jako osobna odbitka, Sambor 1902. Ogłosił przekład książki Hermanna von Hlemholza Termodynamika działań chemicznych w warszawskich „Pracach Matematycznych” w 1892 r. Przez szereg lat (1880-1888) w „Kosmosie” prowadził stałą kronikę naukową oraz zamieścił wiele recenzji w pismach naukowych polskich i zagranicznych. Wydał też podręczniki szkolne: Chemia dla klas wyższych gimnazjalnych, Przemyśl 1880; Fizyka dla niższych klas szkół średnich (wraz z Antonim Medardem Kaweckim), Kraków 1892 (oraz trzy kolejne wydania); Fizyka i krótki kurs kosmografii i chemii. Podręcznik dla niższych klas szkół średnich (wraz z A.M. Kaweckim), Kraków 1892 (sześć kolejnych wydań); Fizyka i krótki kurs kosmografii. Podręcznik dla wyższych klas szkót średnich (wraz z A.M. Kaweckim), Kraków 1899 (wyd. 3, Kraków 1904; wyd. 4, Kraków 1906; wyd. 5, Kraków 1913; wyd. 6, Lwów 1925 - przystosował do nowych programów Karol Czajkowski). 
nych i nagród, „Muzeum” 1885, t. 1, s. 497-506; Czego potrzeba do racjonalnej nauki fizyki, ibidem 1885; Wnioski $w$ sprawie uroczystych odpraw i nagród, ibidem 1887, s. 400-410²4; cykl artykułów pt. O Towarzystwie Nauczycieli Szkół Wyższych na łamach „Biblioteki Warszawskiej” (1887, 1890), a w 1891 r. - „Przeglądu Powszechnego”. Ponadto przez szereg lat współpracował z lwowskim dziennikiem „Słowo Polskie”, wypowiadając się w różnych sprawach oświatowych, politycznych czy finansowych ${ }^{25}$. Jego aktywność naukowa w latach samborskich zdecydowanie zmalała, co wynikało z nowych i licznych obowiązków zawodowych, jak i aktywności w życiu społecznym.

Tomaszewski zmarł 17 lipca 1912 r., po ciężkiej chorobie, w wieku zaledwie 60 lat $^{26}$. Z małżeństwa ze Stanisławą z Dziedzickich (córką Ignacego Dziedzickiego, zmarłego 4 grudnia 1903 r. w Samborze w wieku 83 lat ${ }^{27}$ ) doczekał się dwóch synów: dr. Zdzisława Tomaszewskiego (lekarza) i dr. Adama Tomaszewskiego (koncypistę prokuratorii skarbu), oraz córki, zamężnej z architektem Noworytą ${ }^{28}$. Pogrzeb Tomaszewskiego odbył się 19 lipca, na trasie z budynku III gimnazjum im. cesarza Franciszka Józefa we Lwowie na Cmentarz Łyczakowski przy udziale tysięcznych tłumów ${ }^{29}$.

\section{Wyzwania i inicjatywy Tomaszewskiego jako dyrektora szkoły}

Tomaszewski jako dyrektor szkoły średniej, wziąwszy pod uwagę ówczesne realia, miał bardzo wysoką pozycję społeczną. Tak było zwłaszcza w takim mieście jak Sambor, co prawda powiatowym, posiadającym własny okręg sądowy, a także niemałą grupę urzędników i dwie parafie (rzymską i greckokatolicką), nie mającym wszakże takiego znaczenia jak choćby sąsiedni Przemyśl, Stanisławów czy Tarnopol - znacznie większe i ważniejsze spośród prowincjonalnych miast Galicji Wschodniej. Dyrektor gimnazjum był najważniejszą osobą w miejscowych stosunkach szkolnych, stojąc dużo wyżej w hierarchii społecznej niż dyrektor seminarium nauczycielskiego, nie mówiąc o przełożonych szkół wydziałowych czy ludowych. Nie ma się zatem co dziwić, że wszelkie jego działania były pilnie obserwowane i komentowane.

${ }^{24}$ Tekst wygłaszany na IV walnym zgromadzeniu TNSW we Lwowie, w dn. 5-6 IV 1887 r., a omawiany na zebraniach krakowskiego koła tej organizacji. Tomaszewski na łamach „Muzeum” ogłaszał też sprawozdania z posiedzeń koła.

25 „Słowo Polskie” R. 17, 1912, nr 331 z 18 VII, s. 2, 5.

26 Ibidem, nr 332 z 19 VII, s. 1.

27 „Nowa Reforma” R. 22, 1903, nr 282 z 10 XII, s. 4; „Tygodnik Samborsko-Drohobycki” R. 4, 1903, nr 49 z 6 XII, s. 2.

28 „Słowo Polskie” R. 17, 1912, nr 331 z 18 VII, s. 3.

${ }^{29}$ Już sama liczba żałobników świadczy o poważaniu, które zmarły zdobył sobie wśród współczesnych. Wśród znanych osobistości świata polityki i oświaty byli bowiem m.in. posłowie dr Stanisław Głąbiński, dr Ernest Adam, dr Henryk Kolischer, dr Józef Buzek, Józef Hudec, Henryk Reizes, wiceprezydent Rady Szkolnej Krajowej dr Ignacy Dembowski, rektor Uniwersytetu Lwowskiego Ludwik Finkiel w towarzystwie profesorów Kazimierza Twardowskiego, Władysława Antoniego Gluzińskiego i Gustawa Roszkowskiego, rektor Akademii Weterynaryjnej Stanisław Królikowski, prezydent Lwowa Józef Neumann z licznymi radnymi, szereg nauczycieli i uczniów oraz innych osób. Egzekwie odprawił sufragan lwowski ks. bp Władysław Bandurski. 
Dużym problemem dla dyrektora było utrzymanie budynku gimnazjalnego. Pomimo iż gmach był nowy, uroczyście poświęcony i oddany do użytku szkoły aż podczas dwóch uroczystości, 5 września i 15 października 1892 r., to nawet wzniosłe zawołanie obok dwugłowego orła nad wejściem - „Labori, virtuti” ${ }^{30}$ nie było w stanie zasłonić wad przy jego konstrukcji. Co więcej, umowa zawarta między rządem a gminą była powodem nieustannych problemów, które rozwiązano dopiero za czasów dyrektora Józefa Szafrana - choć rząd wybudował budynek, to miasto musiało płacić $5 \%$ rocznie podatku czynszowego i w całości łożyć na wszelkie koszty. Zostały one dopiero zredukowane decyzją cesarską z 21 grudnia 1900 r. A że obiekt nie został najlepiej wykonany, więc nie minęła nawet dekada i trzeba było wykonać przebudowę wszystkich pieców w gimnazjum na koszt miasta - z kamyczkowych na kaflowe. Co więcej, gmina corocznie dopłacała 1000 koron do pensji nauczycielskich ${ }^{31}$. Ważne zatem było, aby członkowie grona nauczycielskiego zasiadali $\mathrm{w}$ różnych gremiach w mieście, w tym i w radzie, i lobbowali za potrzebami środowiska gimnazjalnego.

Już zaledwie pół roku po przybyciu Tomaszewskiego do Sambora, z jego inicjatywy w II półroczu roku szkolnego 1896/1897 odbył się kurs wydziałowy matematyczno-przyrodniczy dla nauczycieli ludowych ${ }^{32}$. Szkoła uroczyście świętowała też 500-lecie odnowienia Uniwersytetu Jagiellońskiego. Wszyscy członkowie grona, $\mathrm{w}$ porozumieniu z nauczycielami z gimnazjów drohobyckiego i stryjskiego podpisali specjalny adres do senatu uczelni, a w uroczystościach centralnych szkołę reprezentował prof. Zenon Eckhardt. Dla młodzieży 7 czerwca 1900 r. urządzono specjalne obchody z programem muzyczno-słownym i przemówieniem dr. W. Szczepańskiego ${ }^{33}$. Po wakacjach, 19 września 1900 r., szkoła świętowała 70-lecie urodzin Franciszka Józefa. Tym razem poza nabożeństwem i akademią przemawiał dyrektor, „podnosząc ważniejsze momenty z pełnego chwały panowania cesarza i wielbiąc wielkie Jego cnoty jako panującego i człowieka" ${ }^{34}$.

$\mathrm{Na}$ wniosek lwowskiego komitetu setnej rocznicy urodzin Adama Mickiewicza samborzanie postanowili urządzić własne obchody. Na ich czele stanął dyrektor Tomaszewski, który „spełnił przyjęty na się obowiązek ku zupełnemu wszystkich zadowoleniu i jemu należy się przed innymi uznanie za to, że uroczystości okazałością i obfitością programu nie uczyniły w tym względzie uszczerbku sławie staremu grodowi naszemu"35. W dn. 21-22 maja 1898 r. miejscowe towarzystwa polskie urządziły obchody obejmujące prelekcje, nabożeństwa, koncert i pochód przez miasto.

${ }^{30}$ H. Grabowicz, Uroczystość poświęcenia i oddania nowego budynku do użytku c.k. gimnazjum, [w:] Sprawozdanie Dyrekcji c.k. Gimnazjum im. Arcyksiężniczki Elżbiety w Samborze za rok szkolny 1893, Sambor 1893, s. 76-82.

${ }^{31}$ Центральний державний історичний архів України, м. Львів (dalej: CDIAU), ф. 178 Rada Szkolna Krajowa, оп. 3, спр. 367, 379; „,Tygodnik Samborsko-Drohobycki” R. 3, 1902, nr 9 z 2 III, s. 4.

${ }_{32}$ Sprawozdanie Dyrekcji c.k. Gimnazjum im. Arcyksiężniczki Elżbiety w Samborze za rok szkolny 1897, Sambor 1897, s. 4.

${ }_{33}$ Ibidem, za rok szkolny 1900, Sambor 1900, s. 4.

${ }^{34}$ Ibidem, za rok szkolny 1901, Sambor 1901, s. 4.

${ }_{35} \mathrm{D}$. Ostrowski, Opis uroczystości, [w:] Uroczystość pamiątkowa setnej rocznicy urodzin wieszcza Adama Mickiewicza święcona w Samborze w maju 1898 r., Sambor 1898, s. 4-5. 
We wszystkich tych wydarzeniach społeczność gimnazjalna brała aktywny udział. Wydano również pamiątkowe wydawnictwo zawierające przemówienia dr. W. Szczepańskiego (s. 3-8) i D. Ostrowskiego (s. 9-16) - drugi z nich był jednym z prelegentów podczas uroczystości.

Nie zawsze jednak działalność Tomaszewskiego odbierano pozytywnie. Tak było w styczniu 1901 r., kiedy na łamach „Tygodnika Samborsko-Drohobyckiego” pojawiła się notka pt. Czy to możliwe? Dywagowano w niej, czy plotka o tym, że Tomaszewski zabronił młodzieży szkolnej udziału w nabożeństwie za powstańców styczniowym, może być prawdziwa. Prawdopodobnie Tomaszewski mógł rozważać taką decyzję, a przez poruszenie sprawy na łamach prasy próbowano go od tej myśli odwieśćc ${ }^{36}$. Również brak zgody Tomaszewskiego, by młodzież szkolna wzięła udział w podwójnym wykładzie dr. Iwana Franki 24 października i 7 listopada 1903 r. o Dantem wywołał zdumienie publicystów miejscowego dziennika ${ }^{37}$. Jakie były pobudki tych decyzji, trudno ustalić z braku innych źródeł. Poglądy polityczne Tomaszewskiego, oscylujące w tym czasie między myślą konserwatywną i narodowo-demokratyczną, mogły powodować, że miejski organ prasowy stale przypatrywał się jego działalności i często ją krytykował, nie wnikając w jej intencje.

Kiedy 7 czerwca 1902 r. do Sambora przybył greckokatolicki ordynariusz przemyski ks. bp Konstantyn Czechowicz, komitet podejmujący biskupa poprosił dyrektora, by młodzież gimnazjalna wzięła udział w urządzaniu szpaleru jako straż honorowa. Ten odmówił, co posłużyło insynuacjom, że zabronił młodzieży udziału w obchodzie 3 maja, a dopiero po naciskach zgodził się udostępnić salę gimnastyczną na użytek miejscowego "Sokoła" ${ }^{38}$. Tomaszewski, korzystając z 19 paragrafu ustawy prasowej, zamieścił sprostowanie, zarzucając redakcji lokalnego tygodnika kłamstwo w sprawie udziału młodzieży w obchodzie święta konstytucji i podkreślając, że odkąd jest dyrektorem, tj. od sześciu lat, Towarzystwo Gimnastyczne korzysta z sali oraz przyległych pomieszczeń, choć ma on prawo ich nie użyczać. Nie ustosunkował się jednak do zarzutu niewzięcia udziału w powitaniu bp. Czechowicza ${ }^{39}$. Również zarząd „Sokoła” napisał sprostowanie. Zaznaczono, że doszło do nieporozumienia z dyrektorem, ale zostało ono już wyjaśnione. Co więcej, po wzniesieniu budynku szkoły przed dziewięcioma laty prawo współużywania sali oraz jednego pokoju na kancelarię i szatnię użyczył towarzystwu ówczesny starostwa samborski, a nie dyrekcja szkoły. A że

${ }^{36}$ „Tygodnik Samborsko-Drohobycki” R. 2, 1901, nr 5 z 3 II, s. 2. Warto pamiętać, że Franko, mimo swoich wysokich kwalifikacji naukowych, ze względu na działalność polityczną był postrzegany jako jeden z głównych wrogów przez rządzących Galicją polskich konserwatystów, co przyczyniło się m.in. do tego, że nie powierzono mu katedry filologii ukraińskiej w Uniwersytecie Lwowskim (zob. szerzej: R. Holyk, Ukraińska filologia na uniwersytecie lwowskim w XIX wieku i w pierwszej połowie XX stulecia. Ludzie, idee, recepcje, „Zeszyty Naukowe Uniwersytetu Jagiellońskiego. Prace Historyczne” 2018, $\mathrm{nr}$ 2(145), W kręgu historii nauki i oświaty. Uniwersyteckie środowiska filologów krakowskich i lwowskich 1850-1939, red. M. Stinia, T. Pudłocki, s. 362-363).

37 „Tygodnik Samborsko-Drohobycki”, R. 4, 1903, nr 44 z 1 XI, s. 2-3; nr 46 z 15 XI, s. 1.

38 Ibidem, R. 3, 1902, nr 24 z 18 VI, s. 2.

39 Ibidem, nr 25 z 22 VI, s. 2. 
budynek był nadal własnością gminy, podkreślano, że tylko gmina mogła „Sokół” pozbawić prawa współużytkowania sali ${ }^{40}$.

$\mathrm{Z}$ tego samego powodu, jak i z braku większych pomieszczeń w mieście sala gimnastyczna służyła na rozmaite potrzeby. Wielokrotnie odbywały się w niej różne inne wydarzenia, organizowane przez instytucje miejskie, przy zgodzie dyrektora Tomaszewskiego. Przykładowo staraniem miejscowego Koła Towarzystwa Szkoły Ludowej urządzono w niej 5 maja 1900 r. wieczór ku czci Sienkiewicza. Otworzyło go słowo wstępne prof. D. Ostrowskiego, dotyczące znaczenia pisarza w życiu Polaków, po którym nastąpiły tzw. żywe obrazy, recytacje i fragmenty z Potopu. Odczytano też list od Sienkiewicza, który dziękował za przesłane życzenia i okolicznościowy adres. Inicjatorami wieczoru byli dyrektor Tomaszewski i nauczyciel miejscowego seminarium nauczycielskiego męskiego Karol Krotochwila ${ }^{41}$. W dn. 24 listopada 1901 r. w sali odbył się wieczór ku czci Mickiewicza, urządzany przez grupę przedmieszczan samborskich $^{42}$. W pomieszczeniu odbywały się wiece polityczne, wystawy czy prelekcje w ramach Powszechnych Wykładów Uniwersyteckich. W ten sposób sprawy szkolne mieszały się z miejskimi, a zainteresowanie opinii publicznej życiem szkoły było zdecydowanie większe, gdyż wielu samborzan miało częsty dostęp do budynku.

Nie tylko użytkowanie sali gimnastycznej stanowiło problem, który odnotowywano w miejscowej prasie. Próbowano naciskać na dyrektora, by wzorem Krakowa, Nowego Sącza i dyrektora gimnazjum kołomyjskiego Józefa Skupniewicza zaangażował się w stworzenie parku Jordana w mieście. Podkreślano, że gmina posiadała sporo nieużytków, które dałoby się zamienić na park, a liczba inteligencji i zamożniejszych obywateli była na tyle duża, że powinna wystarczyć do jego założenia i utrzymywania $^{43}$. Rada Miasta odmówiła jednak Tomaszewskiemu przekazania części terenów miejskich na boisko dla uczniów podczas posiedzenia 1 lipca $1904 \mathrm{r}^{44}$ Po latach ideę uda się zrealizować dopiero jego następcy ${ }^{45}$.

\section{Praca z uczniami}

Kiedy pod koniec roku 1895/96 dyrektor Ignacy Petelenz został przeniesiony z Sambora do I Szkoły Realnej w Krakowie, w miejscowym gimnazjum było 444 uczniów: 286 Polaków oraz 158 Rusinów. Liczba Żydów każdego roku była minimalna, co stanowiło rzadkość w porównaniu z innymi szkołami średnimi w Galicji. We wrześniu $1896 \mathrm{r}$. naukę rozpoczęło 492 chłopców - stawiało to szkołę pod względem liczby pobierającej naukę młodzieży na 16 miejscu w Galicji pośród 30 krajowych gimnazjów ${ }^{46}$. Po kilku latach przyrost był znaczny - na początku roku szkolnego

${ }^{40}$ Ibidem, nr 26 z 29 VI, s. 3.

${ }^{41}$ Ibidem, R. 1, 1900, nr 14 z 29 IV, s. 3; nr 17 z 20 V, s. 2.

${ }^{42}$ Ibidem, R. 2, 1901, nr 47 z 24 XI, s. 2.

${ }^{43}$ Ibidem, nr 22 z 2 VI, s. 2.

${ }^{44}$ Ibidem, R. 5,1904, nr 27 z 3 VII, s. 1.

45 T. Pudłocki, Gimnazjum im. Arcyksiężniczki..., s. 119.

${ }^{46}$ Sprawozdanie c.k. Rady Szkolnej Krajowej o stanie szkót średnich galicyjskich w roku szkolnym 1895/6, Lwów 1896, s. 3, VI. Zob. też: Statystyka szkót średnich Galicji, „Muzeum” R. 14, 1898, z. 1, s. 3. 
1902/1903 przyjęto 607 uczniów. Miejscowa placówka należała do bardziej przepełnionych w kraju, choć daleko jej był do rekordzistów typu: I gimnazjum w Przemyślu (770 uczniów), gimnazjum Franciszka Józefa we Lwowie (850), IV gimnazjum we Lwowie (1018) czy gimnazjum w Rzeszowie (1042) ${ }^{47}$. Warto zaznaczyć, że wbrew niektórym badaczom, pomimo znacznego odsetka uczniów Rusinów (Ukraińców) i kilku nauczycieli nie-Polaków szkoła miała w omawianym czasie zdecydowanie polski charakter, zgodnie z tym, jak prowadzili ją kolejni dyrektorzy ${ }^{48}$.

$\mathrm{W}$ prasie podkreślano, że młodzież miejscowa nie była majętna. Niewielką pomoc finansową dla ubogich chłopców dawały bieżące składki do puszki, wrzucane na bieżąco przez nauczycieli i uczniów, czy datki przekazywane przez osoby prywatne. Towarzystwo Pomocy Naukowej w Samborze zajmowało się wypożyczaniem podręczników szkolnych, a także sporadycznie udzielało zapomóg finansowych ${ }^{49}$. W danym roku szkolnym maksymalnie dwóch uczniów mogło liczyć na stypendia rozdawane z puli, którą dysponował Wydział Krajowy we Lwowie ${ }^{50}$. Rada miejska dysponowała ponadto jednym stypendium $\mathrm{z}$ funduszu im. arcyksięcia Rudolfa, które przyznawała na wniosek dyrektora. Jako że dyrektor był równocześnie radnym miejskim, kontrolował, komu faktycznie $\mathrm{w}$ danym roku jest przyznawane stypendium $\mathrm{z}$ tej puli ${ }^{51}$.

Młodzież mogła korzystać z bursy gimnazjalnej założonej od początku roku szkolnego 1893/1894. Kierował nią katecheta rzymskokatolicki ks. Aleksy Watulewicz; opiekunem chłopców był Teofil Zosel ${ }^{52}$. Przykładowo latem 1902 r. bursa zapewniała 35 miejsc pełnopłatnych, ale ani jednego zniżkowego czy bezpłatnego. W poprzednich latach gwarantowano kilka miejsc nieodpłatnych - w roku szkolnym 1896/97 było ich osiem ${ }^{53}$. Co więcej, uczeń do podania musiał dołączyć świadectwo ukończenia klasy lub zaświadczenie o przyjęciu do szkoły, deklarację opiekuna o gotowości pokrywania czesnego, a także własne książki, przybory naukowej, „łóżko żelazne”, pościel i bieliznę, której praniem miał się sam zajmować, oraz łyżkę, nóż i widelec ${ }^{54}$.

Skoro bursa zapewniała tak mało miejsc, to uczniowie nieposiadający rodziców czy prawnych opiekunów mieszkających w Samborze musieli mieszkać na stancjach ${ }^{55}$. Prasa od czasu do czasu narzekała na ich fatalne warunki:

47 „Tygodnik Samborsko-Drohobycki” R. 3, 1902, nr 48 z 30 XI, s. 3.

${ }^{48}$ М. Кріль, Самбірська гімназія, шлях у 225 років..., passim.

${ }^{49}$ Sprawozdanie Dyrekcji c.k. Gimnazjum im. Arcyksiężniczki Elżbiety w Samborze za rok szkolny 1897, Sambor 1897, s. 27.

${ }^{50}$ Zob. np. „Tygodnik Samborsko-Drohobycki” R. 2, 1901, nr 5 z 3 II, s. 2.

${ }^{51}$ Zob. np. ibidem, R. 3, 1902, nr 22 z 1 VI, s. 2.

${ }^{52}$ Sprawozdanie Dyrekcji c.k. Gimnazjum im. Arcyksiężniczki Elżbiety w Samborze za rok szkolny 1893, Sambor 1893, s. 112; ibidem za rok szkolny 1894, s. 73; ibidem za rok 1897, s. 28; ibidem za rok 1898, s. 27; ibidem za rok szkolny 1903, s. 26.

${ }_{53}$ Ibidem za rok 1897, Sambor 1897, s. 27.

54 „Tygodnik Samborsko-Drohobycki” R. 3, 1902, nr 28 z 13 VII, s. 3.

${ }^{55}$ Przykładowo znany pisarz Stefan Grabiński, w pierwszych latach szkolnych pobierający naukę w gimnazjum samborskim, mieszkał początkowo na stancji, a potem u swojej babci przy ul. Lwowskiej, regularnie jeżdżąc pociągiem do rodziców mieszkających w Łące - zob. J. Maje wska, Demon ruchu, duch czasu, widma miejsc. Fantastyczny Grabiński i jego świat, Wrocław 2018, s. 17-18. 
Jest tu kilka miejsc, gdzie po ośmiu studentów, wraz z gospodynią i jej rodziną, mieści się w dwóch małych izdebkach. Nie ma mowy naturalnie o tym, by każdy z uczniów miał swe osobno łóżko! Synowie biednych wieśniaków lub też wyrobników, którzy nieraz z głodu przymierając garną się do nauki, zmuszeni są do tych stosunków, gdyż im nikt pomocy nie udziela... nie mają protekcji! Istnieje tu wprawdzie bursa gimnazjalna, lecz mieści ona w sobie z małymi wyjątkami jedynie „płatnych wybrańców”! Jakże często zdarza się, że uczeń, który przez całe gimnazjum walczył ciężko z biedą, ginie u kresu studiów ${ }^{56}$.

Nawoływano zatem dyrektora Tomaszewskiego, by nie tylko pilniej przyglądał się oferowanym miejscom dla uczniów, ale próbował wpłynąć na ich jakość. Sugerowano, że nawet niektóre stancje mieszczące się w rynku, a więc w samym centrum miasta, wymagały kontroli ${ }^{57}$. Ówczesna prasa bynajmniej nie przesadzała w swoich nawoływaniach, by ratować dorastające pokolenie. Niemal co roku bowiem zdarzały się przypadki śmierci wśród młodzieży. W większości był to skutek słabego zdrowia, wywołanego nędznymi warunkami zamieszkania czy dorabianiem ponad młode siły. Przykładowo w dn. 9 listopada 1899 r. na szkarlatynę zmarł uczeń IV klasy Stanisław Ficowski, a 6 czerwca 1900 r. uczeń II klasy Leon Jeluk. Niespełna dwa lata później, 17 lutego 1902 r. zmarł w wieku 19 lat uczeń VI klasy Wawrzyniec Marczak, a 7 maja 1902 r. w wieku 16 lat uczeń V klasy Mikołaj Biliński. W większości przypadków dyrektor wraz z delegacją nauczycieli i uczniów brał udział w ich ceremoniach pogrzebowych ${ }^{58}$.

Wyrabianiu odpowiednich postaw wśród młodzieży służyło też wychowanie religijne. Obejmowało ono cykl wielu nabożeństw, nauk i praktyk, w których musieli brać udział uczniowie, kontrolowani nie tylko przez katechetów, ale i nauczycieli świeckich ${ }^{59}$. Pomimo iż za czasów Tomaszewskiego, 31 października 1897 r., nastąpiło poświęcenie kaplicy gimnazjalnej, urządzonej obok auli ${ }^{60}$, nigdzie nie trafiłem na narzekania na nadmierny klerykalizm czy panoszące się religianctwo w szkole. A nie było to wcale rzadkie w ówczesnych realiach, zwłaszcza gdy katecheci nie byli zbyt lotni umysłowo lub gdy dyrektorzy pod płaszczykiem religijności pozwalali na zbyt dużą ingerencję księży w wychowanie i życie w gimnazjach ${ }^{61}$. Ze względu jednak na

56 „Tygodnik Samborsko-Drohobycki” R. 1, 1900, nr 2 z 4 II, s. 2.

${ }^{57}$ Ibidem.

58 Sprawozdanie Dyrekcji c.k. Gimnazjum im. Arcyksiężniczki Elżbiety w Samborze za rok szkolny 1899, Sambor 1899, s. 7; ibidem za rok 1900, s. 4; „Tygodnik Samborsko-Drohobycki” R. 3, 1902, nr 8 z 23 II, s. 3 , nr 19 z 11 V, s. 3.

${ }_{59}$ Zob. dla porównania szerzej: T. Pudłocki, Rola religii $w$ życiu codziennym społeczeństw gimnazjalnych na przykładzie szkót średnich Przemyśla w latach 1867-1939, [w:] Карпати. Людина, етнос, цивілізація, Вип. 3, Івано-Франківськ 2011, s. 59-68.

${ }^{60}$ Sprawozdanie Dyrekcji c.k. Gimnazjum im. Arcyksiężniczki Elżbiety w Samborze za rok szkolny 1898 , Sambor 1898 , s. 4.

${ }_{61}$ Zob. m.in. T. Pudłocki, Na rozstaju wzorców i pragnień - życie codzienne uczniów I gimnazjum w Przemyślu na początku XX wieku, [w:] Virtuti et ingenio. Księga pamiątkowa dedykowana profesorowi Julianowi Dybcowi, red. A.K. B a na ch, Kraków 2013, s. 431-447; idem, „Grono nauczycielskie już nie jest tak zharmonizowane jak było dawniej" - środowisko profesorów dębickiego gimnazjum przed I wojnq światowa, [w:] Prowincja galicyjska wokót I wojny światowej. Konteksty, porównania, przykłady, red. T. Pudłocki, A.S. Więch, Przemyśl 2014, s. 9-21; ide m, Katecheci gimnazjalni obu obrządków kato- 
wykształcenie Tomaszewskiego i podkreślanie przez niego znaczenia nauk matematyczno-przyrodniczych w życiu publicznym umiał on zachować odpowiedni dystans do kwestii wiary i właściwie pogodzić nauczanie religii, obowiązujące przepisy co do praktyk oraz wychowanie młodzieży w duchu nowoczesności. Jedynymi wizytami wyższych hierarchów w szkole były odwiedziny 13 kwietnia 1902 r. ordynariusza przemyskiej diecezji łacińskiej bp. Józefa Sebastiana Pelczara, a dwa miesiące później, 9 czerwca 1902 r., ordynariusza przemyskiej diecezji greckokatolickiej bp. Konstantego Czechowicza. Trudno je jednak uznać za przejaw klerykalizmu ${ }^{62}$.

Poza wpływaniem na moralność starano się też dbać o zdrowie i rozwój fizyczny chłopców. Temu służyły wycieczki w najbliższe okolice miasta i uczęszczanie na ślizgawkę w porze zimowej ${ }^{63}$. Jedyną większą inicjatywą za czasów dyrektury Tomaszewskiego była wyprawa w dn. 18-22 czerwca 1899 r. do Krakowa i zwiedzanie zabytków tego miasta pod przewodnictwem prof. Edmunda Ciąglewicza ${ }^{64}$.

Młodzież nie miała poza tymi, nielicznymi zresztą, inicjatywami większych rozrywek, zwłaszcza że ówczesne przepisy krępowały inicjatywy pedagogiczne i na wiele form wychowawczych nie pozwalały. Niepisanym jednak świętem młodzieży polskiej były coroczne wieczory dedykowane pamięci Adama Mickiewicza. Naturalnie odbywały się one według scenariusza zaakceptowanego przez władze szkolne i pod kontrolą nauczycieli, ale stanowiły okazję do popisów aktorskich, deklamacyjnych i muzycznych przede wszystkim młodzieńców ze starszych klas. Po wieczorze 8 grudnia 1900 r. wiele pochlebnych słów napisano później w miejscowym tygodniku:

Już od kilku dni panowało wśród publiczności samborskiej ogromne zaciekawienie, rzadki popyt za biletami wstępu. I rzeczywiście. Wieczorki urządzane staraniem naszej młodzieży zostały wśród publiczności naszego grodu ogromną sympatię. I przyznać należy zasłużyły na to zupełnie. I tegoroczny wieczorem wypadł pod każdym względem wcale dobrze ${ }^{65}$.

lickich w Galicji Wschodniej w II połowie XIX wieku: razem czy osobno?, [w:] Iсторія реліzіï в Україні. Науковий щорічник, Книга I, упорядники: О. Киричук, М. Омельчук, І. Киричук, Львів 2015, s. 173-189, idem, Apostołowie wiary czy posłuszni urzędnicy? Księża obrządków rzymskokatolickiego i greckokatolickiego w przemyskim I Gimnazjum w latach 1867-1914, [w:] Super omnia veritas. Księga dedykowana Księdzu Profesorowi Tadeuszowi Śliwie w 90. rocznicę urodzin i 50-lecie pracy naukowej, red. J. Wołczański, S. Nabywaniec, A. Szal, Lwów-Kraków 2015, s. 551-580.

${ }^{62}$ Sprawozdanie Dyrekcji c.k. Gimnazjum im. Arcyksiężniczki Elżbiety w Samborze za rok szkolny 1902, Sambor 1902, s. 5. Pelczar był znany ze swego zainteresowania sprawami oświatowymi i licznymi odwiedzinami szkół. Zob. szerzej: H. B orcz, Działalność duszpasterstwa biskupa Józefa Sebastiana Pelczara $w$ diecezji przemyskiej w latach 1901-1924, [w:] Święty Józef Sebastian Pelczar (1842-1924). Rektor Uniwersytetu Jagiellońskiego i biskup przemyski, „Studia do Dziejów Wydziału Teologicznego Uniwersytetu Jagiellońskiego", Kraków 2005, t. 17, s. 375-391. Dla porównania zob. T. Pudłocki, Kontakty bpa Józefa Sebastiana Pelczara z I Gimnazjum w Przemyślu, „Rocznik Gimnazjalny. I Liceum Ogólnokształcące im. J. Słowackiego w Przemyślu” 2003 [2004], nr 7 (86), s. 317-333.

${ }^{63}$ Sprawozdanie Dyrekcji c.k. Gimnazjum im. Arcyksiężniczki Elżbiety w Samborze za rok szkolny 1897, Sambor 1897, s. 28.

${ }^{64}$ Ibidem za rok szkolny 1899, Sambor 1899, s. 6.

65 „Tygodnik Samborsko-Drohobycki” R. 1, 1900, nr 47 z 16 XII, s. 2. Zob. też: ibidem, nr 45 z 2 XII, s. 2. Już pierwszy wieczorek mickiewiczowski, urządzony za czasów Tomaszewskiego, tj. 12 XII 1896 r., zdobył uznanie prasy, która podkreślała nie tylko dobrą oprawę artystyczną uczniów, kierowanych przez 
Kiedy 6 grudnia 1902 r. młodzież urządziła wieczorek mickiewiczowski, na jego zakończenie przemawiał dyrektor.

W pięknych słowach określił on stosunek wieszcza do narodu i przyrównał mickiewiczowskich Filaretów do współczesnej młodzieży, rozbitej na najrozmaitsze obozy i kierunki, wśród których zatraca się pamięć poczucia narodowego. „Jednością silni” w pracy nad sobą i nad drugimi, możemy tylko stworzyć silne i zdrowe społeczeństwo, możemy osiągnąć niepodległość, wolność i potęgę, taką, jakąśmy się cieszyli za Piastów i Jagiellonów. Lecz aby tę wymarzoną i krwią bohaterów zlaną Ojczyzną otrzymać, by Jej białe i nieskalane sztandary powiały i zaszumiały nad gorączkowaną i rozdartą Europą, trzeba nie zatracać energii i mocy, trzeba „,ramieniem do ramienia, wspólnymi łańcuchy opasać ziemskie kolisko, zestrzelić myśli w jedno ognisko i w jedno ognisko duchy”, trzeba dążyć i działać w imię „Tej, która nie zginęła”"

W grudniu 1903 r. na zakończenie wieczoru, tym razem poświęconego życiu i twórczości trzech wieszczów, przemawiał Z. Eckhardt. I on, podobnie jak jego przełożony rok wcześniej, odwoływał się do ideałów przyświecających wileńskim romantykom, nawołując młodzież do ich naśladowania ${ }^{67}$.

Poza corocznymi uroczystościami ku czci Mickiewicza młodzież ukraińska zawsze w marcu świętowała urodziny Tarasa Szewczenki ${ }^{68}$. Dyrektor pozwalał ponadto gimnazjalistom na udział w miejskich obchodach Konstytucji 3 maja. W poszczególnych latach ich organizacja spoczywała na miejskich towarzystwach polskich, ale chłopcy w mundurkach zawsze stanowili dodatkowe uatrakcyjnienie tradycyjnych pochodów ${ }^{69}$.

$\mathrm{W}$ razie trudnych sytuacji wychowawczych i udowodnienia uczniom złamania przepisów szkolnych dotyczących zachowania się w szkole i poza nią najpierw dyrektor zwoływał nadzwyczajne posiedzenie grona nauczycielskiego. Niestety, nie zachowały się protokoły z tych zebrań i jeżeli już wiadomo o podejmowanych uchwałach, to z kilku przykładów korespondencji Tomaszewskiego z przełożonymi, tj. Radą Szkolną Krajową we Lwowie. Przykładowo 22 maja 1901 r. Tomaszewski informował nadzór, że w pełni zgadzał się z decyzją grona o wykluczeniu ucznia klasy III Kazimierza Skulskiego ze szkoły „za napad na p. Albinę Kasprzykównę”. Przy okazji zaznaczył, że kara ośmiu godzin karceru dla ucznia VIII klasy Jana Lewickiego za spoliczkowanie publiczne na ulicy kolegi Judy Rappaporta była za niska. Sugerował szesnaście godzin karceru i dodawał, że „gdyby to nie był uczeń klasy VIII, który za dwa miesiące zakład opuszcza, należałoby go za zniesławienie munduru i zakładu przez czyn brutalny, po-

\footnotetext{
prof. Włodzimierza Budzynowskiego, ale i przemówienie nowego dyrektora. Jak zaznaczono, urządzenie uroczystości „zarówno pięknie świadczy o charakterze i intencjach tak kierownika zakładu, jako też i młodzieży” - zob. „Gazeta Samborska” R. 3, 1896, nr 16 z 21 XII, s. 2.

66 „Tygodnik Samborsko-Drohobycki” R. 3, 1902, nr 50 z 14 XII, s. 1.

${ }^{67}$ Ibidem, R. 4, 1903, nr 52 z 27 XII, s. 3.

68 Zob. m.in. Sprawozdanie Dyrekcji c.k. Gimnazjum im. Arcyksiężniczki Elżbiety w Samborze za rok szkolny 1898, Sambor 1898, s. 4; ibidem za rok 1900, s. 4.

${ }^{69}$ Zob. np. „Tygodnik Samborsko-Drohobycki” R. 4, 1903, nr 19 z 10 V, s. 1.
} 
pełniony na miejscu publicznym wykluczyć z zakładu"70. Sprawa kłótni uczniowskiej podzieliła grono, które stanęło po stronie Lewickiego, a wbrew kierownikowi szkoły. Przełożony próbował wpływać na kolegów, sugerując, że nawet jeśli Rappaport jest uczniem niesympatycznym i postąpił niehonorowo wobec Lewickiego, to zachowanie tego drugiego było niewspółmierne wobec przewiny. Okazało się jednak, że wbrew naciskom dyrektora, grono podjęło dokładnie taką samą uchwałę, „a jeden z najmłodszych członków grona odezwał się nawet, że żałuje, że nie postawiłem wniosku na 4 godziny karceru" "11. Ostatecznie Rada Szkolna Krajowa w piśmie z 14 czerwca 1901 r. całkowicie stanęła po stronie dyrektora, zarówno w przypadku Skulskiego, jak i jego interpretacji zachowania Lewickiego ${ }^{72}$.

W innym przypadku, w piśmie z 8 lipca 1901 r. dyrektor Tomaszewski prosił Radę Szkolną Krajową o obniżenie kary dla ucznia Mariana Koladżyna. Władze zwierzchnie za kradzież płaszcza i róż ze szkoły wydaliły go ze wszystkich szkół Galicji. Dyrektor, po konsultacji z katechetą greckokatolickim ks. H. Gmitrykiem, prosił jedynie o wyrzucenie Koladżyna ze szkoły. RSK podtrzymała jednak swoją decyzję ${ }^{73}$. Podobna kara spotkała ucznia IV klasy Mikołaja Kurylaka, który - złapany na kradzieży książek - decyzją Rady Szkolnej Krajowej z sierpnia 1901 r. został wydalony ze wszystkich szkół Galicji ${ }^{74}$. Kwestia przyznawania kar i nagród nie była odrębna w stosunku do szkół w innych miastach, niemniej jednak w porównaniu z innymi młodzież samborska za czasów Tomaszewskiego wydaje się dość karna i posłuszna. Pojedyncze przykłady łamania przypisów nie były tak nagminne jak w niektórych szkołach średnich.

\section{Grono nauczycielskie}

Zgodnie z ówczesnymi przepisami dyrektorów szkół średnich na wniosek władz oświatowych mianował cesarz. Tomaszewski został powołany na dyrektora gimnazjum samborskiego na mocy decyzji Franciszka Józefa I z 30 sierpnia 1896 r., o czym zawiadomiła go Rada Szkolna Krajowa decyzją z 9 września. Kilka dni później, 16 września objął urzędowanie, a już 22 września żegnał odjeżdżającego do Krakowa swego poprzednika - dyrektora Ignacego Petelenza ${ }^{75}$. Razem $\mathrm{z}$ nim grono nauczycielskie liczyło dwadzieścia dwie osoby - liczba ta niewiele wzrosła w kolejnych latach. Była ona typowa w tym czasie ${ }^{76}$. Wśród nauczycieli znajdowało się co najmniej kil-

${ }^{70}$ CDIAU, ф. 178, оп. 3, спр. 81, к. 44.

${ }^{71}$ Ibidem, k. 44v.

72 Ibidem, k. 45.

${ }^{73}$ Ibidem, k. 36-38.

${ }^{74}$ Ibidem, k. 34.

${ }^{75}$ Sprawozdanie Dyrekcji c.k. Gimnazjum im. Arcyksiężniczki Elżbiety w Samborze za rok szkolny 1897, Sambor 1897, s. 4; „Gazeta Samborska” R. 3, 1896, nr 11 z 1 X, s. 2. Miejscowy dwutygodnik niewiele napisał o tej nominacji, poza tym, że Tomaszewski był profesorem gimnazjalnym z Krakowa - zob. „Gazeta Samborska” R. 3, 1896, nr 10 z 4 IX, s. 2.

${ }^{76}$ Zob. szerzej: H. Kramarz, Nauczyciele gimnazjalni w Galicji 1867-1914. Studium historycznosocjologiczne, Kraków 1987, s. 22-23. Autorka wymienia gimnazjum samborskie jako jedno z liczniej- 
ka wybijających się osób (na długo przed przybyciem nowego dyrektora do Grodu Spytkowego) i aż sześciu z nich posiadało ósmą rangę służbową, co w tej liczbie było rzadkością, zwłaszcza w szkołach na prowincji. Wydaje się, że w czasach Tomaszewskiego grono składało się w dużej mierze z osób ambitnych, a ogólna atmosfera panująca między nauczycielami nie była zła. Nie natrafiłem na żadne przypadki większego konfliktu pomiędzy nauczycielami, a awans Tomaszewskiego do Lwowa świadczy o tym, że władze szkolne były zadowolone z jego dyrektury i sposobu kierowania powierzoną mu placówką.

Przede wszystkim dyrektor dbał o obchodzenie ważnych jubileuszy w życiu kolegów, jak np. 25-lecie kapłaństwa ks. Aleksego Watulewicza, uroczyście świętowane przez społeczność szkolną 27 czerwca 1899 r. ${ }^{77}$ Kiedy Mikołaj Łaszkiewicz i Emil Paszkiewicz odchodzili na emeryturę, dyrektor 13 września 1899 r. urządził im pożegnanie, podkreślając ich wkład w pracę na rzecz środowiska szkolnego ${ }^{78}$. Tomaszewski pamiętał też o zmarłych kolegach i udziale w ich ceremoniach pogrzebowych, jak np. Wojciecha Sołtysa (zm. 1 kwietnia 1899 r.) czy Jana Lityńskiego (zm. 30 listopada 1899 r. ${ }^{79}$. Nie były to nadzwyczajne formy integracji środowiska, ale choćby ich wymienianie w sprawozdaniach szkolnych świadczy o tym, że dyrektorowi zależało na docenianiu podwładnych - czy to za ich życia, czy po śmierci.

Wśród najbardziej aktywnych pedagogów, którzy odgrywali znaczną rolę w życiu miasta i związani byli dłużej z miejscowym środowiskiem, byli obaj katecheci szkolni - rzymskokatolicki ks. Aleksy Watulewicz i greckokatolicki ks. Hilarion Gmitryk - profesor w ósmej, a po latach w siódmej randze, tytularny radca konsystorza w Przemyślu ${ }^{80}$. Pierwszy z nich był na przełomie XIX i XX w. członkiem wydziału Ogniska Polskiego. Organizacja ta skupiała się głównie na prowadzeniu własnej biblioteki i pozyskiwaniu funduszy na zakup nowych książek. Sporadycznie włączała się w organizację obchodów narodowych ${ }^{81}$. Ze względu na to, że Ognisko nie przejawiało większej działalności, próbowano połączyć je z miejscowym Kasynem Powszechnym. Zebrania przedstawicieli obu instytucji w dn. 5 i 11 maja 1903 r. niewiele jednak dały. Ks. Watulewicz reprezentował na nim Ognisko, a inny członek grona, Maksymilian Krynicki, był działaczem Kasyna ${ }^{82}$. Drugi z nich został ostatecznie profesorem w siódmej randze i członkiem komisji egzaminacyjnej dla kandydatów na nauczycieli szkół ludowych; nie udało mu się w 1904 r. wejść do Rady Miejskiej ${ }^{33}$.

szych pod kątem liczby pracujących nauczycieli, co jednak nie jest zgodne z prawdą, gdy weźmie się pod uwagę dane w sprawozdaniach szkoły za poszczególne lata.

${ }_{77}$ Sprawozdanie Dyrekcji c.k. Gimnazjum im. Arcyksiężniczki Elżbiety w Samborze za rok szkolny 1899, Sambor 1899, s. 6-7.

78 Ibidem za rok szkolny 1900, Sambor 1900, s. 5-6.

${ }^{79}$ Ibidem za rok szkolny 1899, Sambor 1899, s. 7; ibidem za rok 1900, s. 4.

80 Державний Архів Львівської області (dalej: DALO), ф. 1262, оп. 58 Gimnazjum im. A. Mickiewicza w Samborze, спр. 193, к. 1-2; Sprawozdanie Dyrekcji c.k. Gimnazjum im. Arcyksiężniczki Elżbiety $w$ Samborze za rok 1908, Sambor 1908, s. X.

81 „Tygodnik Samborsko-Drohobycki” R. 1, 1900, nr 1 z 28 I, s. 2.

82 Ibidem, R. 4, 1903, nr 19 z 10 V, s. 3.

${ }_{83}$ Sprawozdanie Dyrekcji c.k. Gimnazjum im. Arcyksiężniczki Elżbiety w Samborze za rok 1905, Sambor 1905, s. II-III, ibidem za rok szkolny 1908, s. X; A. Puszka, Nauczyciele historii i geografii pań- 
Długoletnimi radnymi miejskimi, wybranymi do tego organu ustawodawczego jeszcze przed przybyciem Tomaszewskiego do Sambora byli: Mikołaj Łaszkiewicz (będący ponadto członkiem miejskiej Kasy Oszczędności) ${ }^{84}$ i dr Wincenty Szczepański (od 6 lutego 1901 r. także członek Kasy) ${ }^{85}$. Ten ostatni był jednym z najbardziej aktywnych członków Towarzystwa Gimnastycznego „Sokół”; 17 września 1906 r. został mianowany dyrektorem Gimnazjum w Gorlicach ${ }^{86}$. W 1899 r. radnym został Edward Berger, a w 1904 r. - Salomon Mandel. Ten drugi był od marca 1901 r. reprezentantem Żydów w Radzie Szkolnej Okręgowej w Samborze, a także kuratorem Szkoły Handlowej Fundacji Ozjasza Gotthelfa. Potem pracował we Lwowie, m.in. jako czynny członek Towarzystwa Nauczycieli Szkół Wyższych ${ }^{87}$.

Zainteresowania polityką i gospodarką przejawiano i w inny sposób. Kiedy 22 października 1903 r. w Samborze zorganizowano wiec przemysłowy, wykład główny wygłosił prof. Michał Bojarski. Miał on już doświadczenie w pracach instytucji promujących polski handel i wytwórczość ${ }^{88}$. Wyjaśnił zgromadzonym znaczenie bogactw naturalnych Galicji i zaapelował o stworzenie nowej organizacji, zajmującej się popieraniem przemysłu krajowego w powiecie, urządzeniem wystawy krajowej w Samborze i naciskaniem na Sejm, by zabezpieczył sumy pieniędzy na rozwój górnictwa. Wśród dyskutantów byli m.in. prof. Andrzej Stopka i adwokat dr Bronisław Potocki - współpracujący z miejscowymi nauczycielami w ramach Uniwersytetu Ludowego. Wybrano komitet, do którego weszli m.in. Bojarski jako sekretarz i dyrektorowa Stanisława Tomaszewska. Nowa organizacja miała zająć się promocją wyrobów krajowych. W dn. 19 marca 1904 r. otwarto w sali gimnastycznej wystawę przemysłu krajowego - po raz kolejny okazało się, że z powodu braku odpowiednich pomieszczeń trzeba było skorzystać z gościnności dyrektora Tomaszewskiego ${ }^{89}$. Z kolei

stwowych szkół średnich w Galicji w okresie autonomii Galicji (1868-1914), Lublin 1999, s. 304; „Tygodnik Samborsko-Drohobycki” R. 5, 1904, nr 26 z 26 VI, s. 2.

${ }^{84}$ Sprawozdanie Dyrekcji c.k. Gimnazjum im. Arcyksiężniczki Elżbiety w Samborze za rok 1897, Sambor 1897, s. 1.

${ }^{85}$ „Tygodnik Samborsko-Drohobycki” R. 2, 1901, nr 6 z 10 II, s. 2.

${ }^{86}$ Sprawozdanie Dyrekcji c.k. Gimnazjum im. Arcyksiężniczki Elżbiety w Samborze za rok 1907, Sambor 1907, s. X; „Tygodnik Samborsko-Drohobycki” R. 6, 1905, nr 1 z 1 I, s. 2. Kiedy Walerian Stauber w V 1905 r. zrezygnował z prezesury w „Sokole”, dr W. Szczepański, który był seniorem i honorowym członkiem organizacji, stanął na jej czele. Pozostał on aktywnym członkiem „Sokoła”, także i w okresie kiedy 7 VI 1905 r. na czele organizacji stanął notariusz dr Jan Kanty Krupiński („Gazeta Samborska” R. 5, 1905, nr 19 z 7 V, s. 3; nr 24 z 11 VI, s. 3; R. 6, 1906, nr 14 z 8 IV, s. 2).

87 Sprawozdanie Dyrekcji c.k. Gimnazjum im. Arcyksiężniczki Elżbiety w Samborze za rok 1899, Sambor 1899, s. 1; ibidem za rok szkolny 1905, Sambor 1905, s. II; ibidem za rok szkolny 1908, Sambor 1905, s. X; „Tygodnik Samborsko-Drohobycki” R. 2, 1901, nr 14 z 7 IV, s. 3; R. 6, 1905, nr 23 z 4 VI, s. 3, nr 37 z 10 IX, s. 3; B. Łu czyńska, Udział Towarzystwa Nauczycieli Szkół Wyższych w integrowaniu nauczycieli szkół średnich Galicji 1884-1909, [w:] Galicja i jej dziedzictwo, t. 3 Nauka i oświata, red. A. Meissner, J. Wyrozumski, Rzeszów 1995, s. 265-266.

${ }_{88}$ Zob. np. M. Bojarski, Kto ma stuszność [o działalności Wytwórczo-Handlowej Spółki przyborów szkolnych pod egidą prof. Antoniego Kaliny], „Tygodnik Samborsko-Drohobycki” R. 4, 1903, nr 24 z 21 V, s. 2.

89 „Tygodnik Samborsko-Drohobycki” R. 4, 1903, nr 43 z 25 X, s. 1; R. 5, 1904, nr 7 z 14 II, s. 1; nr 11 z 13 III, s. 2; nr 13 z 27 III, s. 1; nr 14 z 3 IV, s. 1; nr 15 z 10 IV, s. 1; nr 16 z 17 IV, s. 1; nr 17 z 24 IV, s. 1. Zob. też: A. Kuczera, op. cit., s. 368. 
5 marca 1904 r. zwołano w Samborze wiec przemysłowy. W wyniku dyskusji, w której udział wzięli m.in. F. Tomaszewski i M. Bojarski, powołano Towarzystwo Pomocy Przemysłowej ${ }^{90}$. Sam główny inicjator, tj. M. Bojarski zaledwie jeszcze pół roku mieszkał w Samborze, bowiem jesienią został przeniesiony do II gimnazjum w Rzeszowie. Przed wyjazdem złożył 20 koron na budowę pomnika T. Kościuszki w Samborze ${ }^{91}$.

Włodzimierz Budzynowski i dr W. Szczepański zaangażowani byli w działalność miejscowego Towarzystwa Muzycznego, jako członkowie zarządu tej instytucji od 13 października 1896 r. Budzynowski przez kilka lat pełnił funkcję dyrektora artystycznego, odpowiadając za organizację regularnych koncertów. Swoje talenty muzyczne wykorzystywał, ucząc w szkole młodzież śpiewu ${ }^{92}$.

Dyrektor Tomaszewski był od 1898 r. prezesem miejscowego koła Towarzystwa Szkoły Ludowej, ożywiając działalność instytucji, która po ustąpieniu z prezesury ks. A. Watulewicza podupadła. Podkreślano, że w tym czasie założono bezpłatną wypożyczalnię książek, a także szkołę dla terminatorów-analfabetów. Niemniej jednak liczba członków TSL - 93 - w roku 1899 r. była nawet jak na Sambor bardzo mała ${ }^{93}$. Członkowie grona nauczycielskiego byli też zaangażowani we wspieranie miejscowej ochronki dla dzieci, płacąc comiesięczne datki na jej utrzymanie. W lutym $1901 \mathrm{r}$. w szeregi członków wstąpili: ks. A. Watulewicz, ks. H. Gmitryk, M. Ptaszyk ${ }^{94}$. Tomaszewski i Ptaszyk byli ponadto członkami Macierzy Szkolnej dla Księstwa Cieszyńskiego, której zadaniem było utrzymywanie gimnazjum polskiego i polskiej szkoły ludowej na Śląsku austriackim ${ }^{95}$.

Zaangażowanie miejscowych nauczycieli w prace miejscowego oddziału Towarzystwa Gimnastycznego „Sokół” wynikały z tradycji, które pozostawił poprzednik Tomaszewskiego - dr Ignacy Petelenz, były pierwszy prezes tej organizacji. Na zebraniu członków 25 lutego 1900 r. wiceprezesem wybrano dr. Szczepańskiego (był nim od dłuższego czasu), a do zarządu weszli: F. Tomaszewski, M. Ptaszyk i T. Zosel ${ }^{96}$. Po dwóch latach, na zebraniu 3 lutego 1902 r. do zarządu wszedł jako sekretarz tylko Ptaszyk; 22 maja 1904 r. do zarządu wybrano Ptaszyka i Szczepańskiego - pierwszy z nich pozostał sekretarzem zarządu, a drugi członkiem-seniorem ${ }^{97}$. Powiązania między gimnazjum a „Sokołem” wynikały również z faktu, że miejscowy oddział nie dysponował w tym czasie odpowiednią salą gimnastyczną, korzystając od czasu wybudowania gimnazjum ze szkolnej ${ }^{98}$. Prawdopodobnie współpraca nie układała się aż

${ }^{90}$ Ibidem, R. 5, 1904, nr 14 z 3 IV, s. 3; nr 16 z 17 IV, s. 2.

${ }_{91}$ Ibidem, nr 38 z 18 IX, s. 2.

${ }_{92}$ „Gazeta Samborska” R. 3, 1896, nr 12 z 17 X, s. 2; Sprawozdanie Dyrekcji c.k. Gimnazjum im. Arcyksiężniczki Elżbiety w Samborze za rok 1897, Sambor 1897, s. 3; ibidem za rok 1898, s. 3; ibidem za rok 1899, s. 3; ibidem za rok 1900, s. 5.

${ }_{93}$ „Gazeta Samborska” R. 3, 1896, nr 15 z 1 XII, s. 3; „Tygodnik Samborsko-Drohobycki” R. 1, 1900, nr 8 z 18 III, s. 3.

94 „Tygodnik Samborsko-Drohobycki” R. 2, 1901, nr 7 z 17 II, s. 3.

${ }_{95}$ Ibidem, R. 4, 1903, nr 8 z 22 II, s. 3, nr 11 z 15 III; s. 3; „Gazeta Samborska” R. 3, 1896, nr 11 z 1 X, s. 3.

96 „Tygodnik Samborsko-Drohobycki” R. 1, 1900, nr 7 z 11 III, s. 2;

${ }_{97}$ Ibidem, R. 3, 1902, nr 19 z 11 V, s. 1; R. 5, 1904, nr 21 z 22 V, s. 2; nr 24 z 12 VI, s. 2.

98 Zob. m.in. Ibidem, R. 3, 1902, nr 19 z 11 V, s. 3. 
tak dobrze, skoro nowy zarząd postanowił przyspieszyć budowę własnego gmachu. Prezes dr W. Stauber i M. Ptaszyk 12 lipca 1903 r. zorganizowali uroczystość poświęcenia kamienia węgielnego pod własny gmach. Do Sambora zjechało się 80 druhów zamiejscowych na czele z prezesem okręgu przemyskiego dr. Leonardem Tarnawskim $^{99}$. Póki gmach nie został wybudowany, do końca obecności Tomaszewskiego w Samborze miejscowy oddział Sokoła mógł korzystać z pomieszczeń szkolnych na dotychczasowych warunkach. Co więcej, kiedy w Samborze w dn. 2-3 lipca 1904 r. odbył się zlot IV okręgu Towarzystw Gimnastycznych „Sokół”, zarząd dziękował Tomaszewskiemu za udzielenie kwater dla zjazdowiczów w salach szkoły ${ }^{100}$.

Profesorowie miejscowego gimnazjum bardzo często zabierali głos jako prelegenci w różnych gremiach. Nie było to nic nadzwyczajnego w tych czasach, kiedy wymagano od profesorów szkół średnich, aby w ramach tzw. misji inteligenckiej angażowali się w sprawy publiczne. Rozmaicie jednak wyglądała skala zjawiska i stopień jej realizacji przez poszczególne osoby. Dyrektor sam dający przykład na pewno działał mobilizująco na kolegów, a taką osobą był Tomaszewski. Przykładowo na początku grudnia 1903 r. w Kasynie Powszechnym Salomon Mandel wygłosił mowę pt. Magnetyzm i elektryczność w praktycznym zastosowaniu ${ }^{101}$. Podczas wieczorku poświęconego powstańcom styczniowym 24 stycznia 1904 r. odczytano wykład dr. W. Szczepańskiego pt. Rzecz o powstaniu w r. 1863. Sam autor nie mógł być obecny z powodu choroby, choć jego przemyślenia określono mianem „pięknego elaboratu”102. O ile trudno stwierdzić, jaki był odzew na te pogadanki w społeczności, tak o wiele więcej można powiedzieć o echach wystąpień stałych prelegentów dwóch najprężniejszych instytucji zajmujących się organizacją prelekcji: Powszechnych Wykładów Uniwersyteckich i Uniwersytetu Ludowego im. A. Mickiewicza. Miejscowy oddział Towarzystwa Nauczycieli Szkół Wyższych, zawiązany z inicjatywy Tomaszewskiego 18 marca 1900 r. i szybko połączony w jedno koło z oddziałem drohobycko-stryjskim, nie przejawiał bowiem większej aktywności. Zebrania odbywały się sporadycznie; dotyczyły głównie spraw zawodowych i wychowawczych. Podkreślano jednak, że możliwość odbywania zebrań na przemian w trzech miejscowościach sprzyjała poznawaniu warunków do pracy i wzajemnej integracji między nauczycielami ${ }^{103}$.

\footnotetext{
${ }^{99}$ Ibidem, R. 4, 1903, nr 29 z 19 VII, s. 1.

${ }^{100}$ Ibidem, R. 5, 1904, nr 28 z 10 VII, s. 1; nr 29 z 17 VII, s. 3. Zob. też: A. Kuczera, op. cit., s. 366-367.

${ }_{101}$ „Tygodnik Samborsko-Drohobycki” R. 4, 1903, nr 50 z 13 XII, s. 3.

102 Ibidem, R. 5, 1904, nr 5 z 31 I, s. 3.

103 Tomaszewski został pierwszym przewodniczącym oddziału, a do wydziału z gimnazjum weszli: M. Krynicki, D. Ostrowski i E. Snopek. Już drugie zebranie urządzono z kołem drohobycko-stryjskim, z którym ostatecznie doszło do połączenia. Potem organizowano zebrania na przemian we wszystkich trzech miejscowościach. Tomaszewski (od 8 XII 1900 r. zastępca przewodniczącego, a od 5 VI 1902 r. przewodniczący) brał udział niemal we wszystkich zebraniach. Przykładowo 5 VI 1902 r. F. Tomaszewski, W. Szczepański, S. Mandel i T. Troskolański dyskutowali nad programem nauczania propedeutyki filozofii w gimnazjach, po wykładzie Karola Wróblewskiego pt. Psychologia i empiria. 8 XII 1903 r. urządzono zebranie w Samborze, na którym prof. Stanisław Niemiec mówił nt. O ile i w jaki sposób można przy dzisiejszym planie lekcyjnym rozbudzić u młodzieży samodzielność, po czym przemawiał $\mathrm{dr}$ A. Winogrodzki nt. Wychowanie umysłowe i fizyczne ze stanowiska higieny. Zebraniu przewodniczył F. Tomaszewski, a w dyskusji udział wzięli Józef Staromiejski, dyrektor gimnazjum w Drohoby-
} 
Gdy Uniwersytet Lwowski zarządził organizację pierwszej tury wykładów powszechnych jesienią 1900 r., miejscowi profesorowie gimnazjalni stanowili trzon prelegentów. Organizacji prelekcji podjął się Tomaszewski, będący zarazem przewodniczącym i jednym $\mathrm{z}$ aktywniejszych mówcó $\mathrm{w}^{104}$. Pod dłuższej przerwie, spowodowanej słabym zainteresowaniem publiczności, działalność miejscowego oddziału wznowiono na przełomie zimy i wiosny $1904 \mathrm{r} \mathrm{r}^{105}$

1 czerwca 1901 r. utworzono w Samborze miejscowy oddział Uniwersytetu Ludowego im. A. Mickiewicza. Szybko okazało się, że nowa placówka tematyką swoich prelekcji zdobyła ogromne zainteresowanie wśród mieszkańcó $w^{106}$. Na jej czele stanął miejscowy adwokat dr Bronisław Potocki, a członkiem zarządu z dn. 1 maja $1903 \mathrm{r}$. został dr Alfred Winogrodzki ${ }^{107}$. Siłami członków wystawiono 27 lutego 1902 r. Wesele Wyspiańskiego, którego poziom mimo paru uwag krytycznych oceniano na tyle dobrze, że napisano: „Usuńcie panowie te braki, a możecie zamarzyć o tryumfie o jakim $\mathrm{z}$ amatorskich teatrów chyba jedyna trupa amatorska przemyska mogła marzyć zrównaniu się ze stołecznymi teatrami” ${ }^{108}$. Główne role odegrali Jędrzej Moraczewski (mieszkający wówczas w Samborze) jako Gospodarz i Helena Kozicka jako Rachela. Przedstawienie powtórzono jeszcze dwukrotnie i jak, zaznaczyła Kozicka: „[...] porwaliśmy całe miasteczko na wyżyny"109. Z kolei 15 marca 1903 r. ufundowano bibliotekę dla dzielnicy samborskiej Średnia ${ }^{110}$. Uniwersytet Ludowy słynął jednak głównie z urządzanych wykładów i pogadanek. Kiedy 15 stycznia 1902 r. dyrektor

czu, a z nauczycieli samborskich A. Winogrodzki i Z. Eckhardt. W wyniku nowych wyborów nowym przewodniczącym został dyr. Staromiejski, jego zastępcami - Tomaszewski i Karol Petelenz, dyrektor gimnazjum w Stryju, a do zarządu z Sambora weszli M. Krynicki i S. Mandel - zob. „Muzeum”, R. 16, 1900, z. 4, s. 289 , z. 11, s. 768-771; R. 17, 1901, z. 2, s. 127-128; R. 19, 1903, z. 2, s. 168-171; R. 20, 1904, z. 1 , s. $78-79$.

10425 XI 1900 dyr. Tomaszewski wygłosił odczyt O powietrzu, 2 XII Benon Jasiński - Trzeci rozbiór Polski, 9 XII Mikołaj Lisiński - O węglu, 16 XII Zenon Eckhardt miał mówić nt. Stanisława Konarskiego, ale ostatecznie S. Mandel wygłosił referat $O$ zjawiskach elektrycznych $w$ powietrzu. W ramach tury zimowej 20 I $1901 \mathrm{r}$. Tomaszewski przedstawił wykład pt. O pradzie elektrycznym w sali domu narodowego, a tydzień później w Drohobyczu - O powietrzu. W dn. 3 i 10 II w Samborze K. Wróblewski mówił O wychowaniu u starożytnych, 17 II M. Ptaszyk - O starożytnych Rzymianach, dyr. Tomaszewski 24 II w Drohobyczu - O promieniach Roentgena, a 3 III w Stryju miał przemówienie pt. Prąd elektryczny $i$ jego skutki. W dn. 3 III 1901 r. w Samborze S. Mandel miał prelekcję O promieniach Roentgena, 31 III B. Janowski - Odrodzenie we Włoszech, a F. Tomaszewski 17 III - O telefonie, 1 i 8 XII - Rozmaite sposoby oświetlenia, a 23 XI 1902 r. - Analiza spektralna i chemia nieba. Zob. „Tygodnik Samborsko-Drohobycki” R. 1, 1900, nr 43 z 18 XI, s. 3, nr 47 z 16 XII, s. 2; R. 2, 1901, nr 3 z 20 I, s. 3; nr 4 z 27 I, s. 2; nr 5 z 3 II, s. 2; nr 6 z 10 II, s. 2; nr 8 z 24 II, s. 3; nr 9 z 3 III, s. 2; nr 11 z 17 III, s. 3; nr 13 z 31 III, s. 2; nr 48 z 1 XII, s. 3 , nr 49 z 8 XII, s. 3; nr 47 z 23 XI, s. 2.

105 Wykłady w tym cyklu wygłosili: 21 II 1904 r. A. Winogrodzki - Krew i jej krążenie, a 28 II System nerwowy w uslugach duszy, 6 i 20 III F. Tomaszewski - O pogodzie i jej przepowiadaniu - zob. „Tygodnik Samborsko-Drohobycki” R. 5, 1904, nr 8 z 21 II, s. 2. W roku wykładowym 1902/1903 Kałusz, Przemyśl i Sambor były wymieniane jako ośrodki, w którym wykłady uniwersyteckie cieszyły się najmniejszym zainteresowaniem (zob. „Słowo Polskie” R. 9, 1904, nr 181 z 16 IV, s. 3).

106 „Tygodnik Samborsko-Drohobycki” R. 3, 1902, nr 20 z 18 V, s. 1.

107 Potocki został ponownie wybrany prezesem na zebraniu 14 V 1902 r. i 1 V 1903 r. - zob. „Tygodnik Samborsko-Drohobycki” R. 3, 1902, nr 21 z 25 V, s. 3; R. 4, 1903, nr 18 z 3 V, s. 3.

108 Ibidem, R. 3, 1902, nr 9 z 2 III, s. 3-4.

109 H. z Gostkowskich Kozicka, op. cit., s. 165.

110 „Tygodnik Samborsko-Drohobycki” R. 4, 1903, nr 12 z 22 III, s. 3. 
Tomaszewski wygłosił pogadankę z zakresu nauk przyrodniczych, w takich słowach ją scharakteryzowano:

Niezwykłą co do treści i formy nazywamy bez wahania tygodniową pogadankę prowadzoną przez dyrektora dr. Tomaszewskiego. Rozpoczął ją wskazaniem poważnego błędu w samokształceniu się ludzi inteligentnych. Każdy wykształcony człowiek uważa za swój obowiązek poznać najnowszą celniejszą powieść, dramat młodego pisarza, przykro mu, że nie zna obrazów głośnych nowych malarzy; słowem postępuje, o ile mu warunki pozwalają, z rozwojem literatury i sztuk pięknych. Wręcz zaś przeciwnie zachowuje się wobec zdobyczy nauk ścisłych i przyrodniczych; tu zna przeważnie tylko nazwiska i tytuły. Brak podstawowego wykształcenia przyrodniczego powoduje zajęcie prawie biernego stanowiska w śledzeniu wyników wiedzy. A bodaj czy nie najwięcej upośledzoną jest królowa nauk przyrodniczych - fizyka? ${ }^{111}$.

Spotkanie polegało głównie na zadawaniu pytań, co było nowością. Sprawozdawca prasowy nie ukrywał, że tematyka, która nurtowała zgromadzonych, była bardzo rozległa, a dotyczyła m.in. wynalazków Jana Szczepanika i Thomasa Edisona, Guglielmo Marconiego, galwanoplastyki oraz praw Newtona. Nowa formuła spotkała się z takim zainteresowaniem, że prelegent obiecał powrócić do Uniwersytetu Ludowego z podobną tematyką. Słowa dotrzymał, gdyż 23 stycznia $1903 \mathrm{r}$. mówił o innych zjawiskach przyrodniczych ${ }^{112}$. Z kolei 27 III 1903 r. wygłosił wykład zatytułowany $O$ rzeczach niezmiernie wielkich i niemizernie małych $w$ przyrodzie i o sposobach ich mierzenia. Jak zaznaczono:

Kwestie, które poruszył p. prelegent, są dla szerokiego ogółu nie tylko zupełnie nieznane, ale także nieprzystępne, $\mathrm{z}$ nauki fizyki i matematyki posiadamy przeważnie nader szczupły zakres wiadomości. Mimo to wykład dał pewne oczywiście najogólniejsze pojęcie zebranym i wpoił $w$ nich to przekonanie, iż pomiary te są rzeczywiście prawdziwie i dokładne $e^{113}$.

5 grudnia 1902 r. Tomaszewski miał odczyt Koniec świata. Miejscowy tygodnik nie tylko streścił jego wywody, ale po raz kolejny pochwalił go jako mówcę, który potrafil przedstawić swoje wywody w zajmujący sposób, a i z humorem ${ }^{114}$.

Innym prelegentem uniwersytetu był prof. Andrzej Stopka, który jeszcze jako praktykant w krakowskim gimnazjum św. Anny zdobył sobie jak najlepszą opinię swego opiekuna, późniejszego słynnego językoznawcy dr. Kazimierza Nitscha ${ }^{115}$.

111 Ibidem, R. 3, 1902, nr 3 z 19 I, s. 3.

112 Ibidem, R. 4, 1903, nr 3 z 18 I, s. 3.

113 Ibidem, nr 13 z 29 III, s. 2.

114 Ibidem, nr 49 z 7 XII, s. 2.

115, „...] na lekcjach języka polskiego w klasie VI b i rozmaitych innych lekcjach przez kilkakrotne kontrolowanie przekonałem się o wielkiej sumienności poprawiania [zadań]. Kandydat okazywał zamiłowanie do przedmiotu i gorliwość w spełnianiu obowiązków, wskutek czego widać było w nauce ciągły postęp, a rezultat końcowy był bardzo dobry. W stosunku do uczniów widać było wielką życzliwość, pomimo pewnego wojskowego tonu w mowie. Ten ton - za mało spokojny - i nierównomierność 
Stopka 17 października 1902 r. mówił w sali Towarzystwa Muzycznego O stylu zakopiańskim, a 6 lutego 1903 r. - o Wyzwoleniu Wyspiańskiego; 27 lutego 1903 r. brał udział w dyskusji nad referatem Wojciecha Kostusia pt. Pesymizm w utworach Ibse$n a^{116}$. Na zebrania uczęszczał też Teodor Mianowski. Gdy 21 listopada 1902 r. Helena Kozicka wykładała o Kazimierzu Wielkim Stanisława Wyspiańskiego, podawał on uzupełnienia do utworu, zwłaszcza pod kątem symbolicznym, wyjaśniając kilka scen dramatu, które prelegentka pominęła. Sam miał 28 listopada 1902 r. wykład o Bolesławie Śmiałym ${ }^{117}$. Również prelekcja Mianowskiego spotkała się z żywym zainteresowaniem. Jak napisano:

Nad odczytem tym wywiązała się ożywiona dyskusja, którą rozpoczął p. dr Tomaszewski, wytykając jako wady poematu, iż charakter króla Bolesława nie został przedstawiony przez poetę zgodnie z prawdą historyczną, że król ów uchodząc z Polski na wygnanie nie mógł żadną miarą myśleć i wyrażać swych uczuć w taki sposób, jak to przedstawił Wyspiański, gdyż tak może czuć i wyrażać swe uczucia tylko współczesny nam poeta dekadent. Poemat Wyspiańskiego jest $\mathrm{w}$ wielu miejscach niejasny $\mathrm{i}$ wymaga do zrozumienia głębokiego namysłu i kilkakrotnego odczytania w przeciwieństwie do utworów naszych wielkich poetów doby romantycznej a zwłaszcza Mickiewicza, którego utwory są dla każdego z łatwością zrozumiałe i wiecznie w literaturze naszej żyć będą jako nieśmiertelne arcydzieła. O naszych współczesnych poetach, przedwcześnie jeszcze sąd ostateczny wypowiadać, dopiero potomni należycie ich ocenią i ostatnie słowo o ich znaczeniu i wielkości orzekną ${ }^{118}$.

Ze zdaniem Tomaszewskiego nie zgodzili się m.in. B. Potocki i A. Stopka - podkreślano jednak wysoki poziom dyskusji i interesujące argumenty używane przez adwersarzy. I dyrektor, i Mianowski zabierali głos podczas zebrania 19 grudnia 1902 r., kiedy omawiano kwestię istnienia duchów. Tomaszewski sceptycznie odniósł się do wszelkich nadzwyczajnych zjawisk, których autentyczności niepodobna sprawdzić, choć zaznaczył, że w ramach hipnotyzmu wciąż pozostaje przed nauką wiele zagadek. Mianowski z kolei powołał się na ówczesną psychologię, podkreślając, że powstawanie widziadeł sennych jest niczym innym jak tylko kojarzeniem wyobrażeń otrzymywanych na jawie ${ }^{119}$. Tomaszewski i Stopka brali udział 30 stycznia 1903 r. w dyskusji nad referatem Tadeusza Wysoczańskiego, który streszczał wywody zawarte w książce Nasza młodziė̇ (Kraków 1902). Obaj nie zgodzili się z wywodami prelegenta, uważając, że zajmowanie się przez młodzież uniwersytecką polityką nie jest rzeczą szkodliwą, ale powoduje zainteresowanie się kwestiami społeczno-politycznymi i generalnie

wymagań były może największymi brakami, które jednak, jak i inne pomniejsze, w ciągu roku prawie zupełnie zostały wyrównane" - CDIAU, ф. 178 Rada Szkolna Krajowa, op. 3, cпр. 48.

116 „Tygodnik Samborsko-Drohobycki” R. 3, 1902, nr 42 z 19 X, s. 4; R. 4, 1903, nr 6 z 8 II, s. 2; nr 7 z 15 II, s. 2; nr 9 z 1 III, s. 3.

${ }_{117}$ Ibidem, R. 3, 1902, nr 47 z 23 XI, s. 2. Niestety, H. z Gostkowskich Kozicka w swoich wspomnieniach nie napisała nic o swojej aktywności w ramach Uniwersytetu Ludowego - zob. eadem, op. cit., passim.

118 „Tygodnik Samborsko-Drohobycki” R. 3, 1902, nr 48 z 30 XI, s. 3.

119 Ibidem, nr 51 z 21 XII, s. 3. 
przyczynia się do uobywatelnienia ${ }^{120}$. Z kolei 30 listopada 1903 r. A Stopka, A. Winogrodzki brali udział w dyskusji nad wystąpieniem Michała Bojarskiego pt. $O$ szczęściu, podważając niektóre z tez swego kolegi z gimnazjum ${ }^{121}$. M. Bojarski 4 i 11 marca 1904 r. miał wykład nt. Słowacki i nowa sztuka przy - jak podkreślano - przepełnionej sali. Z jego wywodami polemizowali stali bywalcy, tj. Winogradzki, Kozicka, Potocki i Stopka, który - według prasy - najwięcej dyskutował z tezami przedstawionymi przez prelegenta ${ }^{122}$. Dr Winogrodzki nie stronił też od prelekcji popularnych, z których będzie słynął i w kolejnych latach ${ }^{123}$.

O tym, że wykłady Uniwersytetu Ludowego cieszyły się ogromnym powodzeniem, świadczy m.in. fakt, że kiedy jesienią 1903 r. miejscowy oddział nie ogłosił nowej tury odczytowej, w lokalnym tygodniku anonimowy Tunik ogłosił artykuł Kilka słów o pogadankach Uniwersytetu Ludowego, odwołując się do idei powołania instytucji i nawołując miejscowy oddział do większej aktywności. Próbował się też rozprawić z oskarżaniem towarzystwa o szerzenie idei socjalistycznych, wyjaśniając, że wykłady z zakresu nauk społecznych i przyrodniczych nie równały się promowaniu jakichkolwiek partii politycznych ${ }^{124}$.

Warto podkreślić, że niektórzy nauczyciele mieli ambicje naukowe i nie ograniczali się wyłącznie do wygłaszania prelekcji popularyzujących naukę. Korzystali oni z głównej płaszczyzny, umożliwiającej druk swoich prac, którą były coroczne sprawozdania dyrekcji szkoły - każde musiało bowiem, w myśl ówczesnych przepisów szkolnych, zawierać rozprawę szkolną. Jak już wielokrotnie było zaznaczone w literaturze, rozprawy te stały na różnym poziomie, ale część z nich wytrzymywała porównanie $\mathrm{z}$ artykułami publikowanymi w pismach naukowych, zwłaszcza że rozprawy te były wielokrotnie recenzowane w rozmaitych periodykach, zarówno galicyjskich, jak i austriackich ${ }^{125}$. Dorobek naukowy ogłaszany w sprawozdaniach za czasów Tomaszewskiego wygląda następująca: dr Emil Petzold w sprawozdaniu za rok szkolny 1896/1897 zamieścił drugą część rozprawy Hölderlins Brod und Wein. Ein exegetischer Versuch (s. 3-110), Dezyderiusz Ostrowski w sprawozdaniu za rok 1897/1898 opublikował cz. 1 Katalogu biblioteki nauczycielskiej c.k. gimnazjum im. Arc. Elżbiety $w$ Samborze $(1-67)^{126}$. Przybytki pozyskiwane do biblioteki drukowano w kolejnych

120 Ibidem, R. 4, 1903, nr 6 z 8 II, s. 2.

121 Ibidem, nr $44 \mathrm{z} 1$ XI, s. 3.

122 Ibidem, R. 5,1904, nr 10 z 6 III, s. 2; nr 11 z 13 III, s. 2.

123 A. Winogrodzki 3 IV 1903 r. mówił o fizjologii i higienie oddychania, 24 X 1903 r. miał wykład pt. Rozwój ziemi, a 27 XI 1903 r. - Alkoholizm i jego rola w organizmie i społeczeństwie - zob. „Tygodnik Samborsko-Drohobycki” R. 4, 1903, nr 13 z 29 III, s. 2; nr 44 z 1 XI, s. 2; nr 48 z 29 XI, s. 3. Na temat jego aktywności w Samborze w dalszych latach zob. T. Pudło cki, Gimnazjum im. Arcyksiężniczki Elżbiety..., s. 105-106.

124 „Tygodnik Samborsko-Drohobycki” R. 4, 1903, nr 42 z 18 X, s. 2.

125 Zob. m.in. A. Horbowski, Sprawozdania szkolne gimnazjów galicyjskich, [w:] Galicja i jej dziedzictwo, t. 3, Nauka i oświata, red. A. Meissner, J. Wyrozumski, Rzeszów 1995, s. 211-219 (tam dalsza szczegółowa literatura).

126 Autor jest wprawdzie niewymieniony z imienia i nazwiska, ale prawdopodobnie nikt inny nie mógł tego katalogu przygotować do druku, skoro to Ostrowski zajmował się biblioteką w ramach swoich obowiązków służbowych. 
sprawozdaniach zawsze na końcu, na stronach I-II. Ponadto w sprawozdaniu za rok szkolnym 1898/1899 ukazała się Uczta Trimalchiona Tytusa Petroniusza Arbitra w tłumaczeniu D. Ostrowskiego (s. 1-38), a w sprawozdaniu za lata 1899/1900 część pierwsza rozprawy Kwestia trylogii tebańskiej u Sofoklesa Arseniego Dorożyńskiego (s. 1-48, cz. 2 opublikował autor w sprawozdaniu gimnazjum w Stanisławowie za rok 1900/1901, na s. 3-49). Dyrektor Tomaszewski w sprawozdaniu za rok 1900/1901 ogłosił drukiem Promienie Roentgena (s. 3-79), Kazimierz Strzelecki w sprawozdaniu za rok 1901/1902 - Morze w Odysei (s. 3-18), Teodor Mianowski w sprawozdaniu za rok 1902/1903 O tzw. pojęciach wrodzonych u Locke'a i Leibniza (s. 1-15), zaś Filaret Kołessa w sprawozdaniu za rok 1903/1904 - Układ „Pamiętników” Ksenofonta o Sokratesie (s. 1-30).

Wśród wymienionych osób, zwłaszcza Petzold zasłynął z prac z zakresu germanistyki. Jego doktorat obroniony w 1897 r. u Ryszarda Wernera na Uniwersytecie Lwowskim, a drukowany w sprawozdaniu samborskim określano jako pionierski, o trwałych walorach naukowych dysertacji. Petzold pracował następnie w szkołach lwowskich, a po habilitacji w 1914 r., w latach 1915/16-1920/21 jako docent prywatny prowadził wykłady z filologii i historii literatury niemieckiej na Uniwersytecie Lwowskim. W r. 1918/19 wykładał również gościnnie na Uniwersytecie Warszawskim (w charakterze docenta tymczasowego), a także prowadził ćwiczenia z nowszego języka i literatury niemieckiej ${ }^{127}$. Z kolei Filaret Kołessa był wybitnym ukraińskim muzykiem, folklorystą i badaczem literatury. Po wielu latach pracy w gimnazjach w Stryju i we Lwowie w roku 1939 r. został profesorem Uniwersytetu Lwowskiego im. I. Franki, a w roku 1940 r. dyrektorem Lwowskiego Muzeum Etnograficznego. Pozostawił po sobie ogromny dorobek naukowy. Uważany jest za założyciela ukraińskiej etnograficznej historii muzyki ${ }^{128}$. Mniejsze znaczenie osiągnęli inni autorzy rozpraw. Dezyderiusz Ostrowski był w późniejszych latach dyrektorem szkół średnich we Lwowie, w Rzeszowie i Poznaniu, a także i pracownikiem Ministerstwa Wyznań Religijnych i Oświecenia Publicznego w Warszawie ${ }^{129}$. Arseni Dorożyński był jednym z prężniejszych nauczycieli w Przemyślu, a potem w Dębicy; pozostawił po sobie niewielki dorobek naukowy ${ }^{130}$.

Z nauczycieli, którzy nie publikowali na łamach sprawozdań, ambicje naukowe miał m.in. dr Tadeusz Troskolański, stały współpracownik „Przewodnik Naukowego i Literackiego”, który po przeniesieniu do Przemyśla, poza pracą w szkolnictwie, był jednym z pierwszych archiwistów miejskich ${ }^{131}$. Emil Paszkiewicz także mógł się

127 J. Starnawski, Petzold Emil, [w:] Słownik badaczy literatury polskiej, t. 2, Łódź 1998, s. 352-354.

128 Zob. szerzej: Енциклопедія українознавства, т. 3, Львів 1993, s. 1081-1082; Т.Ю. Галайчак, Колесса Філарет Михайлович, [w:] Енциклопедія історії Украйни, ред. В.А. Смолій, т. 4, Київ 2007, s. 451.

129 Szkoła charakterów. Księga Jubileuszowa I Gimnazjum i Liceum w Rzeszowie, oprac. J. Świ eb od a, Rzeszów 1985, s. 92, 100, 103.

${ }_{130}$ Zob. szerzej: T. Pudłocki, A.S. Więch, Dorożyński Arseni, [w:] Przemyski słownik biograficz$n y$, t. 2, Przemyśl 2011, s. 8-11.

${ }_{131}$ Zob. szerzej: E. Grin-Piszczek, Troskolański Tadeusz Franciszek, [w:] Przemyski słownik biograficzny, t. 2, Przemyśl 2011, s. 169-173. 
poszczycić dorobkiem naukowym, z zakresu filologii łacińskiej ${ }^{132}$. Franciszek Nowosielski za swoje prace naukowe został w 1885 r. członkiem Komisji Fizjograficznej Akademii Umiejętności w Krakowie, a 10 września 1897 r. został mianowany kierownikiem nowo otwartej szkoły realnej w Tarnowie ${ }^{133}$. Duże znaczenie w nauce osiągnął Herman Sternbach, który pozostawił po sobie bogaty dorobek naukowy z zakresu germanistyki i innych filologii. Jego poezje, drukowane w języku niemieckim, jak Dunkle Stunden (Dresden 1904); Ein Erntelied der Liebe und des Lebens (Leipzig 1906), okazjonalnie były drukowane w przekładzie na język polski w miejscowej prasie. Po wielu latach pracy w Samborze, w r. szk. 1928/9 przeniósł się do Lwowa, gdzie nadal uczył języka niemieckiego w V Gimnazjum im. Hetmana Stanisława Żółkiewskiego i był od 1931 r. docentem germanistyki na Uniwersytecie Jana Kazimierza ${ }^{134}$. $\mathrm{Na}$ łamach miejscowej prasy w tym czasie opublikował artykuł Goethe w Polsce ${ }^{135}$. Naturalnie i dyrektor Tomaszewski miał znaczny dorobek naukowy. Jego osiągnięcia doceniono poprzez mianowanie go na członka Komisji Fizjograficznej Akademii Umiejętności w Krakowie 4 kwietnia 1900 r. ${ }^{136}$

Jednym z najbardziej zaangażowanych poza murami szkoły nauczycieli był Zenon Eckhardt. Związał się z Samborem na długie lata, a po wojnie został dyrektorem miejscowego Gimnazjum Żeńskiego im. M. Konopnickiej. Udało mu się doprowadzić do założenia miejscowego oddziału Towarzystwa Rękodzielników i Przemysłowców „Gwiazda”, i to w niedługim czasie po przeniesieniu do pracy w Samborze w $1898 \mathrm{r}$. Na czele pierwszego oddziału stanął ks. Franciszek Dobrowolski, wikariusz rzymskokatolickiej parafii w Samborze. Eckhardt został wiceprezesem, a kuratorami wybrano dyrektora Tomaszewskiego, ks. Franciszka Rabieja (greckokatolickiego katechetę wydziałowej szkoły żeńskiej) i notariusza Alojzego Schneidra. Po przeniesieniu ks. Dobrowolskiego do Turki, a potem do Przeworska, po roku prezesem wybrano ks. Władysława Makowca - katechetę w seminarium nauczycielskim męskim ${ }^{137}$. Początkowo „Gwiazda” liczyła 96 członków, których liczba wzrosła po dwóch latach do 148. Wynikało to $\mathrm{z}$ faktu, że organizacja ta szybko stała się centrum życia miejscowych Polaków, organizującym wieczorki patriotyczne, wykłady i zabawy taneczne, opłatki i święcone, a także służącym pomocą materialną dla swoich członków ${ }^{138}$. Eckhardt 11 lutego

${ }^{132}$ Opublikował m.in. na łamach samborskich sprawozdań: De Horatii et Augusti necessitudione quee ex carminibus lyricis intellegitur (1876, s. 3-19), System koniugacji łacińskiej (1884, s. 3-48), De Horatio Homeri imitatore (1888, s. 1-16), Arystotelesa Konstytucja Aten (część historyczna) (1894, s. 3-45).

${ }_{133}$ Archiwum Nauki PAN i PAU w Krakowie (dalej: AN), PAU KF - 1, k. 113; Sprawozdanie Dyrekcji c.k. Gimnazjum im. Arcyksiężniczki Elżbiety w Samborze za rok 1897, Sambor 1897, s. 1; ibidem za rok 1898, s. 4. Ogłosił on m.in. w sprawozdaniu dyrekcji gimnazjum w Samborze za rok 1882 pracę pt. Niektóre własności układu dwóch i więcej kół (Sambor 1882, s. 3-39).

${ }_{134}$ DALO, ф. 1262, оп. 58 Gimnazjum im. A. Mickiewicza w Samborze, спр. 193, к. 9-10; „Gazeta Samborska" R. 5, 1905, nr 7 z 12 II, s. 3; nr 8 z 19 II, s. 2; M. Kłańska, Sternbach Herman, [w:] Polski słownik biograficzny, Warszawa-Kraków 2004-2005, t. 43, s. 471-473.

135 „Tygodnik Samborsko-Drohobycki” R. 2, 1901 nr 49 z 8 XII, s. 1; nr 50 z 15 XII, s. 1; nr 52 z 22 XII, s. 1; nr 53 z 29 XII, s. 2.

${ }_{136}$ AN, Dziennik podawczy Akademii Umiejętności, 1900, nr 128.

137 Schematismus universi venerabilis cleri saecularis et regularis doecesis rit. lat. premisliensis pro anno 1900, Premisliae 1900, s. 215-216; ibidem za rok 1901, s. 216, 220; ibidem za rok 1902, s. 179, 253.

${ }_{138}$ Zob. m.in. „Tygodnik Samborsko-Drohobycki” R. 2, 1901, nr 3 z 20 I, s. 3. 
1900 r. należał on do organizatorów wieczoru ku czci Teofila Lenartowicza, a trzy tygodnie później, 4 marca kierował uroczystością z okazji śmierci kuriera Szymona Konarskiego ${ }^{139}$. W dn. 25 marca 1900 r. na zebraniu „Gwiazdy” dyrektor Tomaszewski wygłosił odczyt pt. O lokomotywach ${ }^{140}$.

\section{Działalność Tomaszewskiego jako radnego i posła w czasach samborskich}

Różnorodne formy aktywności Tomaszewskiego i umiejętności godzenia życia zawodowego, naukowego i zaangażowania w sprawy społeczne spowodowały, że stosunkowo szybko zdobył on zaufanie samborzan i w roku $1901 \mathrm{r}$. wybrano go radnym miejskim. Przeglądając sprawozdania prasowe z obrad rady, odnosi się wrażenie, że zabierał głos często, i to w przeróżnych sprawach - od kwestii oświatowych, przez budowlane, podatkowe, higieny, estetyki w mieście, czy wreszcie dotyczące spraw bardziej ogólnych (galicyjskich czy państwowych), aktualnie poruszanych podczas obrad. Trudno przytoczyć wszystkie przykłady jego zaangażowania w prace lokalnego samorządu, ale choć kilka daje wyobrażenie o tym, co go interesowało i w jakie sprawy angażował się najbardziej.

Przykładowo na zebraniu Rady Miejskiej 19 lutego 1902 r. Tomaszewski postawił wniosek, by na przedmieściu Średnia wybudować szkołę ludową, co uchwalono ${ }^{141}$. To on, na polecenie rady, sprawdzał bieżące wydatki gminne za rok 1901, z czego zdawał sprawę przed radą 7 maja i 3 września 1902 r. ${ }^{142}$ Podczas zebrania 10 września $1902 \mathrm{r}$. poruszył kwestię handlu na placu targowym. Podkreślił, że mieszczanie skarżą się, iż sklepikarze - wbrew regulaminowi - wykupują cały towar zanim zwykli mieszkańcy zdążą zrobić sprawunki, co powodowało albo brak potrzebnych wiktuałów, albo ich straszną drożynę. Poparł go prof. M. Łaszkiewicz, zaznaczając, że częściowo to wina zjeżdżających do Sambora kupców z Drohobycza, Borysławia, Truskawca i Turki ${ }^{143}$. Do sprawy drożyzny i braku towarów w mieście obaj radni-nauczyciele wracali nie raz. Z kolei Tomaszewski kilkukrotnie publicznie apelował do burmistrza, by ten pilnował realizacji uchwał podejmowanych przez radnych, gdyż, jak pokazywała rzeczywistość, często tego nie robiono.

Tomaszewski, z ramienia rady miejskiej, od 22 października 1902 r. zasiadał w Towarzystwie Opieki nad Internatem Uczniów Seminarium Nauczycielskiego; powołano go również do komisji, mającej wystarać się o założenie w mieście seminarium żeńskiego ${ }^{144}$. W dn. 3 lutego 1904 r. wybrano go przez rajców na członka miejskiej Kasy Oszczędności ${ }^{145}$. Z kolei na posiedzeniu 2 marca 1903 r. został jednym z siedmiu członków z rady miejskiej, którzy zasiadali w samborskiej radzie powiatowej.

\footnotetext{
139 Ibidem, R. 1, 1900, nr 4 z 18 II, s. 3; nr 5 z 25 III, s. 4; nr 7 z 11 III, s. 2.

140 Ibidem, nr 9 z 25 III, s. 2.

141 Ibidem, R. 3, 1902, nr 8 z 23 II, s. 1.

142 Ibidem, nr 20 z 18 V, s. 2; nr 36 z 7 IX, s. 2.

143 Ibidem, nr 37 z 14 IX, s. 1.

144 Ibidem, nr 45 z 9 XI, s. 2.

145 Ibidem, R. 5, 1904, nr 6 z 7 II, s. 1; nr 8 z 21 II, s. 2.
} 
18 marca 1903 r. na zebraniu rady powiatowej wszedł do jej wydziału jako zastępca członka $^{146}$, a 18 grudnia 1903 r. powołano go do komisji zajmującej się uregulowaniem stosunków prawnych tzw. korporacji obywateli miejskich w Samborze z powodu nieprawidłowości finansowych, mających miejsce w tej instytucji ${ }^{147}$. To on był inicjatorem powołania pośród radnych tzw. delegacji szkolnych, których zadaniem była kontrola zachowania uczniów w przestrzeni miejskiej. Pomimo jednak nacisków ze strony pomysłodawcy delegacje nigdy się nie zebrały, a jak pisano: „Tymczasem młodzież, jak w ubiegłych latach, tak i obecnie, mimo istnienia delegacji odwiedza kawiarnie nocne, szynki itp. lokale"148.

Tomaszewski po kilku latach pobytu nad Dniestrem miał tak mocną pozycję, że latem 1901 r. postanowił wystartować w wyborach do Sejmu Krajowego we Lwowie. Podczas wiecu przedwyborczego 24 sierpnia Tomaszewski streszczał swój program. Był za uchwaleniem piątej kurii do sejmu i za prawem bezpośredniego tajnego głosowania dla wszystkich dorosłych mężczyzn. Uważał, że namiestnik powinien być odpowiedzialny przez sejmem, jak ministrowie są odpowiedzialni przed radą państwa. Najważniejszymi aktualnymi problemami, z którymi borykało się społeczeństwo, były - według niego - rozwój szkolnictwa oraz rolnictwa i przemysłu, a także poprawa doli nauczycieli. Pomimo iż z przekonania był konserwatystą, przyrzekł wstąpić do klubu demokratycznego po wyborach ${ }^{149}$. Jego konkurentami byli: wiceburmistrz dr Józef Steuermann, ziemianin Władysław Popiel oraz okoliczny chłop, członek Stronnictwa Ludowego Jan Ziemniak. „Tygodnik Samborsko-Drohobycki” ewidentnie forował Popiela, stając w jego obronie nawet przed atakami lwowskiego „Słowa Polskiego"150. Walka była dość zawzięta. Podczas wiecu 1 września Tomaszewskiego nieoczekiwanie zaatakował jego były wychowanek, maturzysta z 1898 r., Jarosław Biliński. Podkreślał:

Dr Tomaszewski jest człowiekiem zacnym i uczciwym (tu spostrzegł mówca jego obecność na sali), ja sam go czczę i poważam [...]. Ale moim zdaniem człowiek ten, lubo na innym polu zasłużony, nie odpowiada swej kandydaturze. [...] Nie zna ludu ten, kto obracał się w sferach wyższych, nie ten, kto stara się o zaszczyty i dyplomy. Czy to jest demokratyzm, gdy się gardzi rękodzielnikiem i chłopem? On jest urzędnikiem i musi iść za rządem lub wyjdzie podczas uchwał z sali, by nie głosować. Dr Tomaszewski jest zawisłym; a ktoś zresztą da nam gwarancję, że wstąpiwszy do klubu demokratycznego nie wystąpi z niego?!151.

Tomaszewski wyraził swoje oburzenie wynurzeniami byłego ucznia, zarzucając mu młody wiek i brak kompetencji, by go oceniać. Niemniej jednak obecni wyciągnęli mu wchodzenie $w$ konszachty $\mathrm{z}$ Władysławem Abrahamem - profesorem

\footnotetext{
146 Ibidem, R. 4, 1903, nr 10 z 8 III, s. 3; nr 12 z 22 III, s. 3.

147 Ibidem, nr 51 z 20 XII, s. 2.

148 „Słowo Polskie” R. 8, 1903, nr 179 z 18 IV, s. 6.

149 „Tygodnik Samborsko-Drohobycki” R. 2, 1901, nr 35 z 1 IX, s. 1-2.

150 Ibidem, nr 35 z 1 IX, s. 5.

${ }^{151}$ Ibidem, nr 36 z 8 IX, s. 2.
} 
Uniwersytetu Lwowskiego i jednym z liderów konserwatystów galicyjskich. Swego przełożonego bronił prof. Karol Wróblewski. Podkreślił on ponadto znaczenie relacji polsko-ukraińskich w życiu społeczno-politycznym, znaczenie zasad demokratycznych, ale równocześnie i brak poszanowania godności własnej i drugich w sferze publicznej. Sprawozdawca miejscowego tygodnika ostatecznie sugerował czytelnikom głosowanie na Popiela i Steuermanna, uważając, że Tomaszewski nie jest on prawdziwym demokratą, a jako urzędnik państwowy nie może być niezależny w swoich wyborach. Co więcej zaznaczono, że układy z konserwatystami oraz fakt, iż jako dyrektor gimnazjum mógł wpływać na decyzje rodziców, miały go dyskwalifikować jako kandydata ${ }^{152}$.

Pomimo nieprzychylnych artykułów i jakoby niewielkich szans na zwycięstwo, to jednak Tomaszewski został 11 września 1901 r. wybrany posłem do Sejmu Krajowego z trzeciej kurii. Otrzymał 453 głosy, a dr Steuermann - 402. Jak pisał nieprzychylny dyrektorowi „Tygodnik Samborsko-Drohobycki”, wynikało to z faktu, że wiele osób uprawnionych do głosowania nie wzięło w nim udziału, a w dniu wyborów, po południu, gdy rozeszła się wiadomość o tym, że dyrektor i wiceburmistrz mają największe szanse na wygraną, za Tomaszewskim mieli agitować miejscowi księża i uczniowie gimnazjalni ${ }^{153}$. Bez względu na to, na ile żale miejscowego tygodnika były prawdziwie, ostatecznie redakcja postanowiła pogodzić się z nowym posłem. Już w kolejnym numerze chwalono jego nowy, powyborczy krok - wstąpienie w szeregi miejscowego „Ogniska Polskiego"154. Było to o tyle łatwiejsze, że władzą w Samborze podzielono się - konkurent Tomaszewskiego, dr Steuermann został 29 stycznia 1902 r. wybrany burmistrzem miasta, ponieważ dotychczasowy, dr Ignacy Budzynowski dość nieoczekiwanie zrezygnował ze stanowiska ${ }^{155}$.

Naturalnie po wyborze do Sejmu Krajowego wzrosły oczekiwania wobec Tomaszewskiego. Już 29 grudnia 1901 r. podczas wiecu polskiego w Samborze zobowiązano go, by w porozumieniu $z$ innymi posłami podniósł sprawę gwałtów wrzesińskich i zaprotestował dosadnie przeciw postepowaniu Niemców wobec polskich dzieci w zaborze pruskim ${ }^{156}$. Dotychczasowi przeciwnicy zaczęli również współpracę na kilku polach, m.in. zostali inicjatorami zawiązania komitetu miejskiego obchodów grunwaldzkich, który 3 sierpnia 1902 r. zorganizował uroczystości miejskie ${ }^{157}$. Jak pisano, wypadły one bardzo okazale. W farze łacińskiej patriotyczne kazanie wygłosił katecheta ks. A. Watulewicz. Na rogu rynku i ulicy prowadzącej do Sądu Obwo-

152 Ibidem, nr 36 z 8 IX, s. 2.

153 Ibidem, nr 37 z 15 IX, s. 1; S. Grodziski, Sejm Krajowy Galicyjski, t. 1-2, Kraków 2018, s. 404.

154 „Tygodnik Samborsko-Drohobycki” R. 2, 1901, nr 38 z 22 IX, s. 2.

155 Ibidem, R. 3, 1902, nr 5 z 2 II, s. 1. Wybory powtórzono na zebraniu 19 II t. r. z powodu, „iż nie było listy podług którego każdy miał głos oddać i nie zanotowano, iż głosował”. Ponownie jednak wybrano dr. Steuermanna. Budzynowski, pełniący różne funkcje i godności w mieście, zmarł kilka miesięcy później, tj. 30 X 1902 r. w wieku 63 lat (ibidem, nr 8 z 23 II, s. 1; nr 44 z 2 XI, s. 2). Steuermanna i jego rodzinę, zasymilowanych Żydów, bardzo dobrze wspomina H. z Gostkowskich Kozicka - zob. eadem, op. cit., s. 157-158.

156 „Tygodnik Samborsko-Drohobycki” R. 3, 1902, nr 1 z 5 I, s. 1.

157 Ibidem, nr 30 z 27 VII, s. 2. 
dowego przemówił burmistrz, zaznaczając, że magistrat postanowił tę ulicę nazwać Jagiellońską, na część zwycięstwa Jagiełły. Następnie w rynku, przed wielkim obrazem króla, przemówił Tomaszewski. Jak zaznaczono:

Mówił przepięknie - szkoda tylko, że całą tą mową nie możemy się podzielić z czytelnikami. Zaznaczył we wstępie, co było powodem sprowadzenia Krzyżaków, i przeszedłszy ich całą historię i stosunek do narodu polskiego, mówił o zwycięstwie pod Grunwaldem i jego znaczeniu dla nas. Następnie wspomniał mówca o obecnych stosunkach i położeniu Polaków, że oprócz tych wrogów, w których niewoli muszą zostawać bracia nasi, tuż obok nas wychowaliśmy sobie innych, również niebezpiecznych, domowych wrogów, którzy starają się nas wyrugować aż za San, ale - da Bóg - zakończył poseł m. Sambora, że oprzemy się Krzyżactwu, nie damy się innym wrogom i nie pójdziemy za San dokąd nas z własnych, morzem łez i krwi okupionych siedzib - gwałtem chcą wysłać. Jędrna ta, patriotyczna i przepiękna mowa wywarła wielkie, głębokie i niezatarte wrażenie na słuchaczach ${ }^{158}$.

Kiedy w dn. 16 sierpnia 1902 r. w sali „Hotelu Narodowego” w Samborze odbył się zjazd delegatów Krajowego Towarzystwa Nauczycieli Ludowych, Tomaszewski referował kwestię polepszenia prac sejmowych nad podwyżką płac dla tej grupy zawodowej. Co więcej, obiecał, że na najbliższej sesji przedłoży wniosek o zmianę postepowania dyscyplinarnego ${ }^{159}$. Gdy 17 marca 1903 r. poseł na Sejm z kurii gmin wiejskich Feliks Sozański zwołał wiec powiatowy w Samborze, Tomaszewski był przewodniczącym zebrania. Poruszano zagadnienie polskiego stanu posiadania w Galicji Wschodniej. Wiec zgromadził też nauczycieli gimnazjalnych, którzy opowiadali się przeciw bagatelizowaniu ruchu ukraińskiego, a za wzmacnianiem polskości, m.in. przez popieranie Towarzystwa Szkoły Ludowej. W tym duchu wypowiadali się M. Bojarski, ks. A. Watulewicz i A. Stopka ${ }^{160}$. Tomaszewski 28 września 1902 r. przewodniczył też zebraniu sprawozdawczemu posła do Rady Państwa, profesora Uniwersytetu Lwowskiego Gustawa Roszkowskiego ${ }^{161}$.

Sprawa polskiej obecności w Galicji Wschodniej mocno nurtowała Tomaszewskiego. W tej kwestii zwołał wiec 5 października 1902 r. w sali samborskiego Hotelu Lwowskiego. Główny referat wygłosił Władysław Popiel z Czerchawy, ale wśród 1500 zgromadzonych nie brakowało i profesorów gimnazjalnych. Michał Bojarski nawoływał do pójścia w ślady Polaków w Złoczowie. Ślubowali oni, że tylko po polsku mówić będą i jedynie z Polakami interesy będą robić, nawet jeśliby to oznaczało straty finansowe. Wśród uchwalonych postulatów podtrzymano te głoszone przez Bojarskiego, dorzucając wiele szczegółowych, w tym dbanie o „czysto polski charakter uniwersytetu lwowskiego"162. Drugi wiec, dotyczący stosunków polsko-żydowskich Tomaszewski zwołał 20 marca 1904 r. Jako główny organizator otworzył spotkanie, które

\footnotetext{
158 Ibidem, nr 32 z 10 VIII, s. 1.

159 Ibidem, nr 34 z 24 VIII, s. 1.

160 Ibidem, R. 4, 1903, nr 12 z 22 III, s. 2.

161 Ibidem, R. 3, 1902, nr 40 z 5 X, s. 2.

162 Ibidem, nr 41 z 12 X, s. 1.
} 
zgromadziło ponad tysiąc osób. W mowie podkreślił, że głównym celem wieców jest budzenie ducha narodowego. I tym razem wykład plenarny wygłosił W. Popiel, popierając asymilację Żydów i wzywając zebranych do jej promowania. Na spotkaniu nie zabrakło profesorów gimnazjalnych, biorących udział w dyskusji, m.in. A. Stopki i M. Bojarskiego ${ }^{163}$.

Inną inicjatywą poselską był zwołany 13 grudnia 1903 r. wiec w celu wyjaśnienia samborzanom znaczenia i sensu składania tzw. podatku narodowego. Zbierano go od wszystkich chętnych na prowadzenie działalności komitetu centralnego, mającego wspierać inicjatywy patriotyczne w całej Galicji. Pomimo iż miejscowy oddział zajmujący się zbiórką zawiązano 17 marca tego roku, a więc kilka miesięcy wcześniej, Tomaszewski ubolewał, że Polacy byli apatyczni i bierni w sprawach ważnych dla całego narodu. Za takową uważał kwestię utrzymania polskiego stanu posiadania i wpływów w Galicji Wschodniej. Jego przemowa spotkała się jednak ze sprzeciwem niektórych samborzan. Zarzucano komitetowi centralnemu, że podatek narodowy tak naprawdę szedł na wsparcie polityczne działalności konserwatystów i nie miał nic wspólnego z inicjatywami wspierającymi funkcjonowanie Polaków. Przykładowo dr B. Potocki zażądał nawet od Tomaszewskiego zwrotu 11 koron, które pierwotnie wpłacił i... kwotę tę przeznaczył na rzecz Domu Polskiego w morawskiej Ostrawie ${ }^{164}$.

Jak każdy inny poseł, ówczesnym zwyczajem Tomaszewski musiał składać przed wyborcami sprawozdania ze swojej pracy. Pierwsze złożył 11 października 1902 r. ${ }^{165}$ Przemawiał do dwustu osób, a podobno zrobił to „z taktem, $\mathrm{z}$ ominięciem wszystkiego, co by razić mogło jednostronnością lub samochwalstwem"166. Z tego, co mówił, wynikało, że przez pierwszy rok skupił się głównie na uzyskaniu podwyżek płac dla nauczycieli. Ponadto nawoływał do zgody narodowej i współdziałania ponadpartyjnego w pracy nad dobrem kraju ${ }^{167}$.

W dn. 17 stycznia 1904 r. złożył kolejne sprawozdanie. Skupił się w nim na omówieniu głównie tarć polsko-ukraińskich i zwalczaniu zapatrywania jakoby Galicja Wschodnia miała być „czysto ruską”. Autor uważał, że rozdział między Polakami i Ukraińcami wynikał głównie z trzech elementów: 1) podburzającej działalności większości pism ukraińskich oraz niektórych mocarstw (nie podał żadnych przykładów), którym zależy na skłóceniu żyjących obok siebie narodów, 2) różnicy obrządków, 3) gorszego położenia ekonomicznego Ukraińców. Tomaszewski uważał, że duża część żali wobec Polaków była nieuzasadniona. Uwypuklił równość językową w Galicji, a także otwieranie szkół z ukraińskim językiem wykładowym. Zaznaczył, że nawet jeśli Sejm podczas ostatniej kadencji odrzucił otwarcie gimnazjum ukraińskiego w Stanisławowie, to dla wielu Ukraińców była to sprawa raczej polityczna niż

\footnotetext{
163 Ibidem, R. 5, 1904, nr 13 z 27 III, s. 1.

164 Ibidem, R. 4, 1903, nr 51 z 20 XII, s. 1; nr 52 z 27 XII, s. 2.

165 Ibidem, R. 3, 1902, nr 41 z 12 X, s. 2.

166 Ibidem, nr 42 z 19 X, s. 2.

167 Ibidem.
} 
oświatowa ${ }^{168}$. Twierdził, że wszelkie zakładane przez Polaków instytucje były otwarte również i dla Ukraińców, czego nie można było powiedzieć o instytucjach ukraińskich, które w dużej mierze zrzeszały tylko „swoich”. Co więcej, w Galicji Wschodniej Kościół greckokatolicki miał więcej parafii niż rzymskokatolicki, trudno było mówić zatem - według niego - o polonizacji tej części kraju w czasach, kiedy to ta instytucja tak mocno wpływała na wykształtowanie się tożsamości narodowej. Naturalnie poglądy mówcy wynikały z jego zapatrywań politycznych i coraz mocniejszego związku z galicyjskimi narodowymi demokratami, jak i z coraz większymi starciami polsko-ukraińskimi w życiu publicznym na początku XX w. ${ }^{169}$ Poza kwestiami narodowościowymi, Tomaszewski dłuższą uwagę poświęcił kwestiom skarbowym, reformie gminnej administracji i konstytucji państwa, zaznaczając, że musi się w niej znaleźć zapis dający większe kompetencje samorządom oraz organom krajowym w kwestiach zarządzania danymi krajami koronnymi ${ }^{170}$.

Zarówno długoletnie doświadczenie, jak i gruntowna znajomość prawa oświatowego sprawiły, że Tomaszewski w Sejmie zabierał głos głównie w sprawach szkolnych; szybko został mianowany sekretarzem sejmowej Komisji Szkolnej. W czasie przemowy sejmowej 15 września 1903 r. w ostrych słowach wypowiadał się przeciw oszczędnościom na płacach dla nauczycieli: „Zapewnijmy nauczycielom przynajmniej pewność posiadania tego, co mają, zapewnijmy im starość bez trosk i goryczy... Nauczycielstwo nie ma pretensji, aby było Benjaminkiem społeczeństwa - jednakże Parjasem jego być nie chce; nie żebrze łaski, ale żąda sprawiedliwości”"171. Tomaszewski podjął sprawę poruszaną wcześniej przez posła Tadeusza Romanowicza - rozszerzenie autonomii Rady Szkolnej Krajowej - i opracował szczegółowy projekt ustawy, którą wniósł pod obrady sejmu wraz z posłem Stanisławem Głąbińskim w roku 1904. Ustawa weszła ostatecznie w 1905 r. i „niewątpliwie olbrzymie zasługi położył Tomaszewski jako projektodawca w ewolucji w naszej administracji szkolnej”172. Już w 1904 r. Tomaszewski zgłosił po raz pierwszy wniosek o utworzenie funduszu krajowego na zaliczki nauczycielskie. Niestety, postulat ten został zrealizowany dopiero sześć lat później. Niezrażony początkową porażką, kontynuował walkę o podwyższenie dotacji zapomogowej dla nauczycieli, żądając wsparcia przede wszystkim dla cho-

${ }^{168}$ Z gimnazjum w Stanisławowie w roku szkolnym 1905/1906 wydzielono filię, z której stopniowo powstało gimnazjum ukraińskie. Na jego czele stał znany ukraiński pedagog Mykoła Sabat - zob. С. Пахолків, Українська інтелікениія у Габсбурзькій Галичині: освічена верства й емансипачія начіï, Львів 2014, s. 234-235.

${ }^{169}$ Literatura na temat relacji polsko-ukraińskich w Galicji jest niezwykle obszerna, i to nie tylko w językach polskim i ukraińskim. Ze względu na to, że nie stanowi ona głównego wątku w niniejszym artykule pozwoliłem sobie na jej pominięcię.

${ }^{170}$ „Tygodnik Samborsko-Drohobycki” R. 5, 1904, nr 4 z 24 I, s. 1.

171 Cyt. za: J. Kor nicki, op. cit., s. 1. Zob. Mowa posła Tomaszewskiego wygłoszona w Sejmie Krajowym 15 września 1903 przy poparciu wniosku o zmianę ustawy o stosunkach prawnych stanu nauczycielskiego („,Tygodnik Samborsko-Drohobycki” R. 4, 1903, nr 41 z 11 X, s. 1-2; nr 42 z 18 X, s. 1; nr 42 z 25 X, s. 1). Zob. też: Mowa posła Dra Fr. Tomaszewskiego, wygłoszona w obronie projektu ustawy o stosunkach prawnych nauczycieli szkół ludowych (ibidem, nr 48 z 29 XI, s. 1; nr 49 z 6 XII, s. 1).

${ }^{172}$ J. Kornicki, op. cit., s. 1. 
rych i potrzebujących kuracji. Jego wystąpienia w obronie Żydów na łamach Sejmu spotkały się z uznaniem miejscowej Izraelskiej Gminy Wyznaniowej ${ }^{173}$.

\section{Zakończenie}

Przy wyjeździe Tomaszewskiego do Lwowa urządzono mu uroczyste pożegnanie na stacji kolejowej. „Tygodnik Samborsko-Drohobycki” tak skomentował uczucia towarzyszące rzeszy osób, odprowdzającej go do pociągu: „[...] wszystkich ogarniał żal za wytrwałym pracownikiem na polu spraw publicznych w Samborze, który [...] w każdej potrzebie publicznej, od której to nigdy się nie usuwał [...] sam podnosił inicjatywę w sprawach ważnych dla dobra ogólnego" ${ }^{174}$. Odjeżdżającego żegnało całe grono nauczycielskie oraz uczniowie z nowo mianowanym dyrektorem Józefem Szafranem, społeczność Seminarium Nauczycielskiego Męskiego, a także przedstawiciele władz autonomicznych, rządowych, reprezentanci rady miejskiej oraz członkowie żydowskiej rady wyznaniowej $\mathrm{z}$ rabinem Aaronem Lewinem na czele ${ }^{175}$.

Uroczystość pożegnania pokazuje, że $\mathrm{w}$ realiach miast prowincjonalnych rola jednostek, zwłaszcza ambitnych i aktywnych w życiu społecznym, była ogromna. Tomaszewski swoją wszechstronną wiedzą, elokwencją, umiejętnościami organizacyjnymi i ogromnym zaangażowaniem w kreowanie przestrzeni publicznej zdobył sobie takie uznanie, że uważano go za jednego z liderów, godnego, by reprezentować mieszkańców na zewnątrz. Był on inicjatorem wielu pożytecznych akcji, swoim przykładem inspirując nie tylko nauczycieli, ale i innych mieszkańców do pracy na rzecz „małej ojczyzny” na tyle skuteczne, że władze oświatowe postanowiły awansować go na dyrektora jednej z najważniejszych placówek oświatowych w Galicji, jaką było prestiżowe Gimnazjum Franciszka Józefa we Lwowie. Co interesujące jednak, mimo wielu wystąpień publicznych na rozmaite tematy i stałej obecności w przestrzeni miejskiej Sambora, nie wprowadził on żadnych innowacji pedagogiczno-wychowawczych w gimnazjum. Raczej mądrze kontynuował zastałe formy kierowania szkołą, choć trzeba mu oddać, że dbał o rozsądne rozdzielenie szkoły od wpływów Kościoła (bez względu na obrządek). Główną osią jego zainteresowań była działalność, bardzo pozytywistyczna w swoim wymiarze, mająca na celu podniesienie rangi Sambora jako ważnego ośrodka na mapie oświatowej, kulturalnej, gospodarczej i politycznej Galicji. Nie można też nie zauważyć, że ze względu na swoje poglądy polityczne nade wszystko forował polską rację stanu w przestrzeni publicznej. Niemniej jednak poglądy, które głosił, i troska, z jaką pochylał się nad miejscowymi sprawami, świadczą o autentycznym zaangażowaniu, a nie jedynie traktowaniu Sambora jako etapu w zawodowej i politycznej karierze. Co prawda nie ma podstaw, by twierdzić, że przed

173 „Tygodnik Samborsko-Drohobycki” R. 4, 1903, nr 49 z 6 XII, s. 2. S. Grodziski w monografii Sejmu Krajowego wymienia go jedynie raz (poza spisem posłów), co by wskazywało, że Tomaszewski był raczej przeciętnym posłem jeżeli chodzi o aktywność i zaangażowanie w prace sejmowe - zob. idem, op. cit., s. 657.

174 „Tygodnik Samborsko-Drohobycki” R. 5, 1904, nr 46 z 13 XI, s. 3.

175 Ibidem. 
przyjazdem Tomaszewskiego do Sambora miejscowe środowisko tkwiło w letargu, a po jego wyjeździe rozbudzona na chwilę aktywność zamarła. Wydaje się, że był on dobrym kontynuatorem poczynań swego poprzednika, Ignacego Petelenza, a równocześnie dał bardzo dobre podstawy do dalszego rozwoju szkoły za czasów Józefa Szafrana, który zastąpił go na stanowisku dyrektora samborskiego gimnazjum.
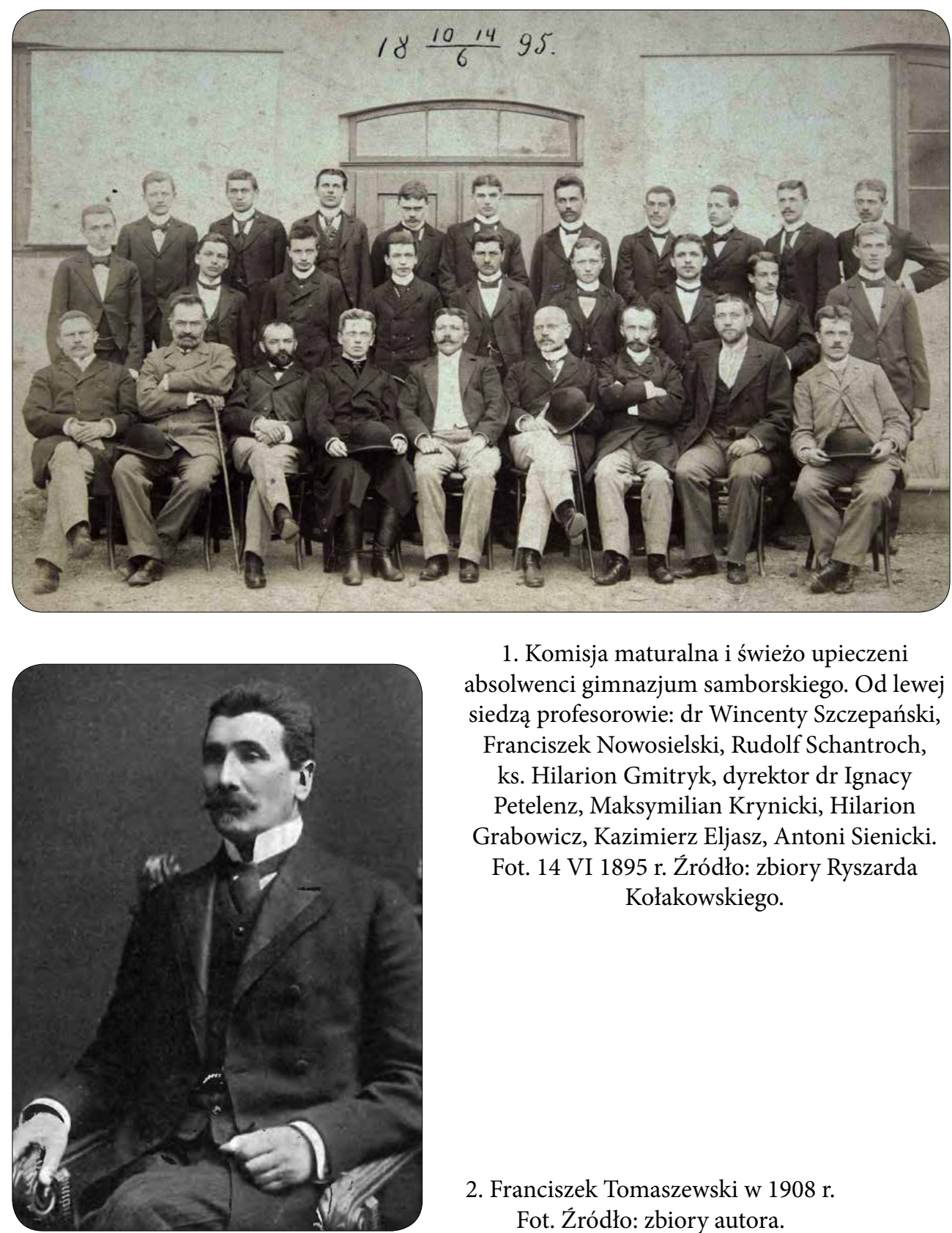

1. Komisja maturalna i świeżo upieczeni absolwenci gimnazjum samborskiego. Od lewej siedzą profesorowie: dr Wincenty Szczepański, Franciszek Nowosielski, Rudolf Schantroch, ks. Hilarion Gmitryk, dyrektor dr Ignacy Petelenz, Maksymilian Krynicki, Hilarion Grabowicz, Kazimierz Eljasz, Antoni Sienicki. Fot. 14 VI 1895 r. Źródło: zbiory Ryszarda Kołakowskiego.

2. Franciszek Tomaszewski w $1908 \mathrm{r}$. Fot. Źródło: zbiory autora. 


\section{Bibliografia}

Źródła archiwalne:

Archiwum Nauki PAN i PAU w Krakowie

Dziennik podawczy Akademii Umiejętności, 1900, nr 128

PAU KF - 1 .

Центральний державний історичний архів України, м. Львів

ф. 178 Rada Szkolna Krajowa, оп. 3, сп. 48, 81, 367, 379.

Державний архів Львівської області

ф. 1262, оп. 58 Gimnazjum im. A. Mickiewicza w Samborze, сп. 193.

\section{Źródła drukowane:}

Schematismus universi venerabilis cleri saecularis et regularis doecesis rit. lat. premisliensis pro anno 1900, Premisliae 1900.

Schematismus universi venerabilis cleri saecularis et regularis doecesis rit. lat. premisliensis pro anno 1901, Premisliae 1901.

Schematismus universi venerabilis cleri saecularis et regularis doecesis rit. lat. premisliensis pro anno 1902, Premisliae 1902.

Sprawozdanie c.k. Rady Szkolnej Krajowej o stanie szkół średnich galicyjskich w roku szkolnym 1895/6, Lwów 1896.

Sprawozdanie Dyrekcji c.k. III Gimnazjum im. cesarza Franciszka Józefa we Lwowie za rok szkolny 1905, Lwów 1905.

Sprawozdanie Dyrekcji c.k. III Gimnazjum im. cesarza Franciszka Józefa we Lwowie za rok szkolny 1908, Lwów 1908.

Sprawozdanie Dyrekcji c.k. III Gimnazjum im. cesarza Franciszka Józefa we Lwowie za rok szkolny 1910, Lwów 1910.

Sprawozdanie Dyrekcji c.k. III Gimnazjum im. cesarza Franciszka Józefa we Lwowie za rok szkolny 1911, Lwów 1911.

Sprawozdanie Dyrekcji c.k. Gimnazjum w Przemyślu za rok szkolny 1880, Przemyśl 1880.

Sprawozdanie Dyrekcji c.k. Gimnazjum w Przemyślu za rok szkolny 1881, Przemyśl 1881.

Sprawozdanie Dyrekcji c.k. Gimnazjum w Samborze za rok szkolny 1882, Sambor 1882.

Sprawozdanie Dyrekcji c.k. Gimnazjum im. Arcyksiężniczki Elżbiety w Samborze za rok szkolny 1893, Sambor 1893.

Sprawozdanie Dyrekcji c.k. Gimnazjum im. Arcyksiężniczki Elżbiety w Samborze za rok szkolny 1894, Sambor 1894.

Sprawozdanie Dyrekcji c.k. Gimnazjum im. Arcyksiężniczki Elżbiety w Samborze za rok szkolny 1897, Sambor 1897.

Sprawozdanie Dyrekcji c.k. Gimnazjum im. Arcyksiężniczki Elżbiety w Samborze za rok szkolny 1898, Sambor 1898.

Sprawozdanie Dyrekcji c.k. Gimnazjum im. Arcyksiężniczki Elżbiety w Samborze za rok szkolny 1899, Sambor 1899.

Sprawozdanie Dyrekcji c.k. Gimnazjum im. Arcyksiężniczki Elżbiety w Samborze za rok szkolny 1900, Sambor 1900. 
Sprawozdanie Dyrekcji c.k. Gimnazjum im. Arcyksiężniczki Elżbiety w Samborze za rok szkolny 1901, Sambor 1901.

Sprawozdanie Dyrekcji c.k. Gimnazjum im. Arcyksiężniczki Elżbiety w Samborze za rok szkolny 1902, Sambor 1902.

Sprawozdanie Dyrekcji c.k. Gimnazjum im. Arcyksiężniczki Elżbiety w Samborze za rok szkolny 1903, Sambor 1903.

Sprawozdanie Dyrekcji c.k. Gimnazjum im. Arcyksiężniczki Elżbiety w Samborze za rok szkolny 1904, Sambor 1904.

Sprawozdanie Dyrekcji c.k. Gimnazjum im. Arcyksiężniczki Elżbiety w Samborze za rok szkolny 1905, Sambor 1905.

Sprawozdanie Dyrekcji c.k. Gimnazjum im. Arcyksiężniczki Elżbiety w Samborze za rok szkolny 1908, Sambor 1908.

Uroczystość pamiątkowa setnej rocznicy urodzin wieszcza Adama Mickiewicza święcona w Samborze w maju 1898 r., Sambor 1898.

\section{Prasa:}

„Gazeta Samborska” 1896.

„Muzeum” 1887, 1898, 1901-1904, 1912.

„Nowa Reforma” 1903.

„Słowo Polskie” 1912.

„Tygodnik Samborsko-Drohobycki” 1901-1904.

\section{Wspomnienia:}

Kozicka H. z Gostkowskich, Wspomnienia z lat 1867-1914, oprac. K. Cybulska, Kielce 2015.

\section{Opracowania:}

Borcz H., Działalność duszpasterstwa biskupa Józefa Sebastiana Pelczara w diecezji przemyskiej w latach 1901-1924, [w:] Święty Józef Sebastian Pelczar (1842-1924). Rektor Uniwersytetu Jagiellońskiego i biskup przemyski, „Studia do Dziejów Wydziału Teologicznego Uniwersytetu Jagiellońskiego", Kraków 2005, t. 17, s. 375-391.

Grabowicz H., Uroczystość poświęcenia i oddania nowego budynku do użytku c.k. gimnazjum, [w:] Sprawozdanie Dyrekcji c.k. Gimnazjum im. Arcyksiężniczki Elżbiety w Samborze za rok szkolny 1893, Sambor 1893, s. 76-82.

Grin-Piszczek E., Troskolański Tadeusz Franciszek, [w:] Przemyski słownik biograficzny, t. 2, Przemyśl 2011, s. 169-173.

Grodziski S., Sejm Krajowy Galicyjski, t. 1-2, Kraków 2018.

Holyk R., Ukrainska filologia na uniwersytecie lwowskim w XIX wieku $i$ w pierwszej połowie XX stulecia. Ludzie, idee, recepcje, „Zeszyty Naukowe Uniwersytetu Jagiellońskiego. Prace Historyczne" 2018, nr 2 (145), W kręgu historii nauki i oświaty. Uniwersyteckie środowiska filologów krakowskich i lwowskich 1850-1939, red. M. Stinia, T. Pudłocki, s. 355-374.

Horbowski A., Sprawozdania szkolne gimnazjów galicyjskich, [w:] Galicja i jej dziedzictwo, t. 3, Nauka i oświata, red. A. Meissner, J. Wyrozumski, Rzeszów 1995, s. 211-219.

Kłańska M., Sternbach Herman, [w:] Polski słownik biograficzny, Warszawa-Kraków 20042005 , t. 43, s. 471-473.

Kramarz H., Nauczyciele gimnazjalni w Galicji 1867-1914. Studium historyczno-socjologiczne, Kraków 1987. 
Kuczera A., Samborszczyzna. Ilustrowana monografia miasta Sambora i ekonomii samborskiej, t. 2, Sambor 1937.

Łuczyńska B., Udział Towarzystwa Nauczycieli Szkół Wyższych w integrowaniu nauczycieli szkół średnich Galicji 1884-1909, [w:] Galicja i jej dziedzictwo, t. 3 Nauka i oświata, red. A. Meissner, J. Wyrozumski, Rzeszów 1995.

Majewska J., Demon ruchu, duch czasu, widma miejsc. Fantastyczny Grabiński i jego świat, Wrocław 2018.

Pudłocki T., Apostołowie wiary czy posłuszni urzędnicy? Księża obrządków rzymskokatolickiego i greckokatolickiego w przemyskim I Gimnazjum w latach 1867-1914, [w:] Super omnia veritas. Księga dedykowana Księdzu Profesorowi Tadeuszowi Śliwie w 90. rocznicę urodzin i 50-lecie pracy naukowej, red. J. Wołczański, S. Nabywaniec, A. Szal, Lwów-Kraków 2015, s. 551-580.

Pudłocki T., Franciszek Tomaszewski i njegovo putovanje po hrvatskim krajevima, „Historijski zbornik" [Zagrzeb] 2016, vol. 68, No. 2, s. 385-410.

Pudłocki T., Gimnazjum im. Arcyksiężniczki Elżbiety w Samborze w okresie dyrektury Józefa Szafrana (1904-1914), [w:] Galicja - mozaika nie tylko narodowa, t. 4, red. U. Jakubowska, Warszawa 2017, s. 95-124.

Pudłocki T., „Grono nauczycielskie już nie jest tak zharmonizowane jak było dawniej” - środowisko profesorów dębickiego gimnazjum przed I wojna światową, [w:] Prowincja galicyjska wokół I wojny światowej. Konteksty, porównania, przykłady, red. T. Pudłocki, A.S. Więch, Przemyśl 2014, s. 9-21

Pudłocki T., Katecheci gimnazjalni obu obrządków katolickich w Galicji Wschodniej w II połowie XIX wieku: razem czy osobno?, [w:] Історія релігії в Україні. Науковий щорічник, Книга I, упорядники: О. Киричук, М. Омельчук, I. Киричук, Львів 2015, s. 173-189.

Pudłocki T., Kontakty bpa Józefa Sebastiana Pelczara z I Gimnazjum w Przemyślu, „Rocznik Gimnazjalny. I Liceum Ogólnokształcące im. J. Słowackiego w Przemyślu” 2003 [2004], nr 7 (86), s. 317-333.

Pudłocki T., Na rozstaju wzorców i pragnień - życie codzienne uczniów I gimnazjum w Przemyślu na początku XX wieku, [w:] Virtuti et ingenio. Księga pamiątkowa dedykowana profesorowi Julianowi Dybcowi, red. Andrzej K. Banach, Kraków 2013, s. 431-447.

Pudłocki T., Rola religii w życiu codziennym społeczeństw gimnazjalnych na przykładzie szkół średnich Przemyśla w latach 1867-1939, [w:] Карпати. Людина, етнос, цивілізація, Вип. 3, Івано-Франківськ 2011, s. 59-68.

Pudłocki T., Михайло Кріль: Самбірська гімназія, илях у 225 років, том 1, Дрогобич, wуd. Коло 2017, ss. 806, „Kwartalnik Historii Nauki i Techniki”, R. 63, 2018, nr 3, s. 137-143

Pudłocki T., A.S. Więch, Dorożyński Arseni, [w:] Przemyski słownik biograficzny, t. 2, Przemyśl 2011, s. 8-11.

Puszka A., Nauczyciele historii i geografii państwowych szkół średnich w Galicji w okresie autonomii Galicji (1868-1914), Lublin 1999.

Starnawski J., Petzold Emil, [w:] Słownik badaczy literatury polskiej, t. 2, Łódź 1998, s. 352-354.

Szkoła charakterów. Księga Jubileuszowa I Gimnazjum i Liceum w Rzeszowie, oprac. J. Świeboda, Rzeszów 1985.

Warmski M., Towarzystwa Nauczycieli Szkót Wyższych 1884-1894. Rys historyczny, Lwów 1894.

Weinfeld I., Ludność miejska Galicji i jej skład wyznaniowy (1881-1910), „Wiadomości Statyczne o Stosunkach Krajowych" 1912, t. 24, z. 2. 
Енциклопедія українознавства, т. 3, Львів 1993, s. 1081-1082.

Галайчак Т.Ю., Колесса Філарет Михайлович, [w:] Еничиклопедія історії Украӥни, ред. В.А. Смолій, т. 4, Київ 2007, s. 451.

Кріль М., Самбірська гімназія. Від заснування до „весни народів” (до 225-річчя від заснування), „Дрогобицький краєзнавчий збірник” 2017, вип. 3 (вип. спец.), s. 31-44. Кріль М., Самбірська гімназія, шлях у 225 років, т. 1, Дрогобич 2017.

Пахолків С., Українська інтелігенція у Габсбурзькій Галичині: освічена верства й емансипація нації, Львів 2014.

\section{Томаш Пудлоцький, Самбірська лімназія під керівництвом Францішека Томашевського (1896-1904)}

Стаття присвячена функціонуванню гімназійної громади в Самборі в період дирекції Францішека Томашевського (1896-1904). Томашевський був одним із тих директорів, яким була не байдужа сиспільно-політична ситуація. Саме він переніс із Кракова до Самбора модель педагога-активіста, зацікавленного наукою та політикою. Його брали за приклад також і вчителі з його школи, які були аніматорами різних ініціатив у галузі культури, науки та економіки. Через те, що будинок гімназії частково був на утриманні муніципалітету міста Самбір, до того ж вчителі брали участь у роботах багатьох місцевих товариств, школа в той час була місцем численних заходів, а ії життя було безперервно у об'єктиві місцевої преси.

Ключові слова: гімназія, Самбір, Францішек Томашевський, освіта, громадська робота

\section{Tomasz Pudłocki, The Middle School in Sambor under Franciszek Tomaszewski (1896-1904)}

The author of the article looks into the activity of the Middle School in Sambor lead by Franciszek Tomaszewski (1896-1904) and the school community. Tomaszewski was a committed teacher, activist and prominent educator interested in politics and learning. His method was greatly inspired by his educational background from Kraków. In Sambor he influenced many culturally, educationally and economically active teachers working under his tutelage. Due to the fact that the school in Sambor was funded by Sambor local government and teachers were active members of numerous local associations, the school was the centre for many events readily reported by the local press.

Keywords: middle school, Sambor, Franciszek Tomaszewski, education, social work 